\title{
Phosphorus attenuation in streams by water-column geochemistry and benthic sediment reactive iron
}

\author{
Zachary P. Simpson ${ }^{1}$, Richard W. McDowell ${ }^{1,2}$, Leo M. Condron ${ }^{1}$ \\ ${ }^{1}$ Department of Soil and Physical Sciences, Lincoln University, Lincoln, 7647, New Zealand \\ $5 \quad{ }^{2}$ AgResearch, Lincoln Science Centre, Lincoln, 7647, New Zealand
}

Correspondence to: Zachary P. Simpson (zpsimpso@gmail.com)

\begin{abstract}
Streams can attenuate inputs of phosphorus (P) and, therefore the likelihood of ecosystem eutrophication. This attenuation is, however, poorly understood, particularly in reference to the geochemical mechanisms involved. In our study, we measured $\mathrm{P}$ attenuation mechanisms in the form of (1) mineral (co-)precipitation from the water-column and (2) $\mathrm{P}$ sorption

10 with benthic sediments. We hypothesized that both mechanisms would vary with catchment geology and, further, that $\mathrm{P}$ sorption would depend on reactive Fe content in sediments. We sampled 31 streams at baseflow conditions, covering a gradient of $\mathrm{P}$ inputs (via land use), hydrological characteristics, and catchment geologies. Geochemical equilibria in the water-column were measured and benthic sediments $(<2 \mathrm{~mm})$ were analyzed for sorption properties and P and iron (Fe) fractions. Neither Pcontaining minerals (e.g., hydroxylapatite) nor calcite-phosphate co-precipitation had the potential to occur. In contrast, in-

15 stream dissolved reactive P (DRP) correlated with labile sediment P (water-soluble and easily reduced Fe-P), but only for streams where hyporheic exchange between the water-column and the coarse sediment porewaters was likely sufficient. The non-labile $\mathrm{P}$ fractions contained most of sediment $\mathrm{P}$ (generally >90\%) and varied with parent geology. Similarly, most sediment Fe was in a recalcitrant form (generally $>90-95 \%$ ). However, despite its small contribution to total sediment Fe, the pool of surface-reactive Fe was a strong predictor for sediment $\mathrm{P}$ sorption potential. Our results suggest that, in these streams, it is the combination of biogeochemical Fe and P cycles and the exchange with the hyporheic zone that attenuates DRP in baseflow. Such combinations are likely to vary spatiotemporally within a catchment and must be considered alongside inputs of $\mathrm{P}$ and sediment if the $\mathrm{P}$ concentrations at baseflow - and eutrophication risk - are to be well managed.
\end{abstract}

\section{Introduction}

The mitigation of phosphorus $(\mathrm{P})$ pollution is necessary to manage the eutrophication of water bodies. The efficacy of mitigation measures is typically hoped for in stream monitoring data - a change within the catchment could decrease export of P downstream - but such effects are easily masked (Meals et al., 2010) due to the many biogeochemical processes integrated into the P signal (Dupas et al., 2018a; Halliday et al., 2012). Once mobilized from land via surface runoff or sub-surface flows (McDowell et al., 2004, 2015), P is repeatedly impeded along its flowpath by biotic and abiotic processes (Huang et al., 2018). This persistence of P gives rise to 'legacy P' (Powers et al., 2016; Sharpley et al., 2013), where past P inputs can take unknown 
https://doi.org/10.5194/bg-2019-400

Preprint. Discussion started: 18 October 2019

(c) Author(s) 2019. CC BY 4.0 License.

\section{(c) (i)}

30 years (decades, centuries) to deplete. For example, McCrackin et al. (2018) estimated that only 6\% of all anthropogenic P inputs to the Baltic Sea drainage basin for 1900-2013 have discharged into the sea. Knowing the mechanisms behind legacy $\mathrm{P}$ will improve predictions of $\mathrm{P}$ transport and thus not only engender wise $\mathrm{P}$ management but appropriate assessment of management as well.

Legacy P refers to the attenuation - and slow trickle downstream - of P across the entire catchment, but perhaps the most

35 reactive flowpath for P is the stream itself (Ensign and Doyle, 2006; Haggard and Sharpley, 2007). At baseflow, P in streams is subject to biotic and abiotic processes which could lead to the transient storage of $\mathrm{P}$ (within the channel or in biota) or its re-mobilization back to the water column (Hall et al., 2013; House, 2003). Both periphyton (Biggs, 2000; Davies and Bothwell, 2012; Hill et al., 2009) and heterotrophic microbes (McDowell, 2003; Mulholland et al., 1997; Muscarella et al., 2014) can assimilate P, especially dissolved reactive P (DRP; mostly orthophosphate but can include labile organic compounds), as it is

40 the most bioavailable P form (Biggs, 2000; Muscarella et al., 2014). The turnover of this assimilated P back to the water column completes one cycle of the biotic P attenuation (or spiraling) mechanism (Ensign and Doyle, 2006; Newbold et al., 1983). Numerous studies on strictly biotic $P$ attenuation, however, conclude that biotic mechanisms are not critical for $P$ attenuation in streams (Griffiths and Johnson, 2018; Hall et al., 2002; Weigelhofer et al., 2018). Instead, abiotic P mechanisms - as influenced by stream biogeochemistry - may be responsible for attenuating P (Jarvie et al., 2006; McDaniel et al., 2009;

45 Stutter et al., 2010). Yet, abiotic (i.e., geochemical) $\mathrm{P}$ attenuation phenomena are poorly studied relative to biotic $\mathrm{P}$ attenuation. To address this gap, we consider two geochemical mechanisms - calcium (Ca) based (co-)precipitation and sediment $\mathrm{P}$ sorption - as the primary components of abiotic $\mathrm{P}$ attenuation in streams.

Calcium-phosphate mineral precipitation and $\mathrm{CaCO}_{3}$ co-precipitation may remove DRP from the water column given sufficient $\mathrm{Ca}, \mathrm{pH}$, and pCO2 (Golterman, 2004; House, 2003; Stumm and Morgan, 1996). This may contribute to the initial removal of

50 DRP from the water column, whereby further adsorption or mineral transformations (e.g., towards hydroxyapatite) may occur (Diaz et al., 1994; Golterman, 1988; Plant and House, 2002). Given the dependence on water-column geochemistry, Ca-based $\mathrm{P}$ attenuation is likely a function of catchment geology (Corman et al., 2015; House, 2003; Mulholland et al., 1997). Indeed, most studies focused on Ca-based P attenuation are largely located in catchments with calcareous (i.e., chalk, karst) geology (Cohen et al., 2013; Diaz et al., 1994; House, 1999; Jarvie et al., 2006). Few studies have considered a range of geologies

55 where other abiotic $\mathrm{P}$ attenuation mechanisms may diminish the importance of Ca-based P attenuation, particularly sediment P sorption.

Benthic stream sediments can have large potential to adsorb P and thus attenuate P inputs (Froelich, 1988; Haggard and Sharpley, 2007; McDowell, 2015), especially for baseflow conditions where water is given time to contact sediments in the hyporheic zone (Harvey, 2016). Stream sediments provide abundant reactive surfaces for P sorption; notably, clay minerals 60 and metal (i.e., iron and aluminum) oxides are strong reaction sites (Gérard, 2016; Golterman, 2004; Parfitt, 1979). Further, amorphous iron (Fe) oxides, a variable fraction of the total sediment Fe pool (Jan et al., 2013; Parsons et al., 2017), have great affinity for P (Goldberg and Sposito, 1984; Lijklema, 1980) and are the primary reaction sites in many non-calcareous streams (Dupas et al., 2018b; van der Grift et al., 2014; Lewandowski and Nützmann, 2010). This sediment sorption can be readily 
https://doi.org/10.5194/bg-2019-400

Preprint. Discussion started: 18 October 2019

(c) Author(s) 2019. CC BY 4.0 License.

(c) (i)

examined via intensity of adsorption and the quantity of $\mathrm{P}$ already complexed with the sediment. Sorption intensity measurements often correlate negatively with in-stream DRP (McDaniel et al., 2009; McDowell, 2015; Weigelhofer et al., 2018) and positively with stream P uptake metrics (Demars, 2008; Haggard et al., 2005; Jarvie et al., 2005). Concordantly, sediments in streams with high P loading (i.e., high sustained DRP concentrations) tend to have diminished sorption ability and greater stores of P (Jarvie et al., 2012; McDowell, 2015), particularly in the more labile and redox-sensitive pools (Lewandowski and Nützmann, 2010).

70 Therefore, in the present study, we examined $\mathrm{P}$ attenuation mechanisms in streams at baseflow via Ca-P geochemistry in the water column, stores of sediment $\mathrm{P}$ and $\mathrm{Fe}$, and $\mathrm{P}$ sorption capacities of sediments. Given that these processes are likely all tied to catchment geology and $\mathrm{P}$ inputs, we sampled waters and benthic sediments of streams in the Canterbury region, New Zealand, covering a variety of geologies, land use, and stream characteristics. We hypothesized that the primary mechanisms responsible for $\mathrm{P}$ attenuation (and therefore related to DRP concentrations) were Ca-based mineral equilibria in the water

75 column and sorption with benthic sediments. Further, we hypothesized that amorphous, reactive Fe was a primary controller of sediment $\mathrm{P}$ sorption, rather than refractory or total Fe pools.

\section{Materials and methods}

\subsection{Study sites}

We sampled 31 streams in the Canterbury region, New Zealand (Fig. 1). The site characteristics are given in Table S1, according to the River Environment Classification (REC) developed for New Zealand (Snelder and Biggs, 2002). Stream sizes were mostly $1^{\text {st }}$ to $5^{\text {th }}$ order, with some $6^{\text {th }}$ and $7^{\text {th }}$ order streams $(n=7)$, and generally included both low-elevation and hilly/mountainous streams. Most of the catchments contained some amount of pastoral land uses (i.e., sheep and dairy farming), reflecting the dominant land use in the Canterbury region. In north Canterbury, basins are characterized by quaternary fluvial gravels with some underlying sedimentary deposits (e.g., limestone); further south, the plains were formed by river-deposited erosion and glacial outwash products (by the Rakaia and Waimakariri Rivers), with some intermittent outcrops of greywacke; Banks Peninsula is characterized by a basalt volcanic geology (Brown, 2001). Using the scheme provided by the REC, catchment geology of the study streams corresponded to alluvium ( $n=15)$, sedimentary (hard and soft sedimentary; $n=10$ ), and volcanic basic $(n=6)$; for presentation and discussion purposes, we grouped the observed data in this paper based on these geology classes (see below). Further, we used the REC to distinguish between two prominent sources of flow for the streams by identifying spring-fed sites $(n=8)$ from the other sites (simply termed here as 'hill-fed'; $n=23$ ).

\subsection{Sampling procedure}

Sediment and stream water samples were collected at each site during baseflow conditions from March to May, 2018 (austral late summer/early autumn). We sampled between 1000 and $1600 \mathrm{~h}$ to minimize possible diel effects on DRP (Cohen et al., 2013; McDowell et al., 2019). Benthic sediments (top 1-3 cm) were collected in-situ with a scoop and wet-sieved in the field 
https://doi.org/10.5194/bg-2019-400

Preprint. Discussion started: 18 October 2019

(c) Author(s) 2019. CC BY 4.0 License.

(c) (i)

95 to $<2 \mathrm{~mm}$. The sieved sediment slurry settled after 30 minutes, where excess water was decanted and $\sim 2 \mathrm{~kg}$ of wet sediment was stored on ice and later refrigerated in the laboratory $\left(4^{\circ} \mathrm{C}\right)$. Sediment sampling locations were targeted within the stream where surface water interacts with benthic sediments; primarily, riffle beds near the centroid of flow were sampled but depositional areas closer to the bank were sampled at sites where the stream was too deep and fast-flowing for practical sampling.

100 Water grab samples were collected from the centroid of flow via wading (approaching site from downstream) or with an extended pole and bottle. Sample bottles were field-rinsed three times before taking a sample at two-thirds of the stream depth. Two subsamples were filtered in the field $(0.45 \mu \mathrm{m})$ while another subsample was left unfiltered (all with minimal headspace); all samples were then stored on ice for transport back to the laboratory followed by either freezing $\left(-20{ }^{\circ} \mathrm{C}\right.$; for ion chromatography, ICP-OES, and dissolved Fe as explained below) or refrigeration $\left(4{ }^{\circ} \mathrm{C}\right)$. In addition, we measured dissolved oxygen and temperature at each stream.

\subsection{Water physicochemical analyses}

Upon return to the laboratory, we immediately measured $\mathrm{pH}$ and conductivity in the unfiltered stream sample. Alkalinity was measured on the filtered sample within $24 \mathrm{~h}$ of collection via Gran's titration method (Gran, 1952), following the protocol of Rounds (2012) with $0.05 \mathrm{M} \mathrm{HCl}$ as the titrant. We also measured DRP on the filtered sample within $24 \mathrm{~h}$ via the malachite-

110 green method (detection limit of $0.006 \mathrm{mg} \mathrm{P} \mathrm{L-1;} \mathrm{Ohno} \mathrm{and} \mathrm{Zibilske,} \mathrm{1991;} \mathrm{D'Angelo} \mathrm{et} \mathrm{al.,} \mathrm{2001)} \mathrm{to} \mathrm{minimize} \mathrm{storage}$ influences (Jarvie et al., 2002). Other analyses on the filtered sample included dissolved anions $\left(\mathrm{F}, \mathrm{Cl}, \mathrm{SO}_{4}, \mathrm{NO}_{3}\right)$ via ion chromatography (detection limits range 0.02 to $0.50 \mathrm{mg} \mathrm{L}^{-1}$ ), cations ( $\mathrm{Al}, \mathrm{Ca}, \mathrm{Fe}, \mathrm{K}, \mathrm{Mg}, \mathrm{Mn}, \mathrm{Na}, \mathrm{Zn}$ ) via ICP-OES (detection limits approximately $0.002 \mathrm{mg} \mathrm{L}^{-1}$ ), and total dissolved Fe via a ferrozine method (see below); other elements (e.g., some trace metals) were below detection. Total suspended solids (TSS; method 2540D (APHA, 2005)) were low in these streams at

115 baseflow (mean of $7 \mathrm{mg} \mathrm{L}^{-1}$ ), so suspended sediment likely had negligible influence on DRP (data not shown). Blanks and duplicate checks were included in each batch of samples to ensure quality of results.

We modified the ferrozine colorimetric method (Stookey, 1970) developed by Viollier et al. (2000) to measure total dissolved $\mathrm{Fe}$ in stream samples and $\mathrm{P}$ fractions (below), as it was cost-effective and provided greater sensitivity than ICP-OES for concentrations $<0.050 \mathrm{mg} \mathrm{Fe} \mathrm{L}^{-1}$. Full details are in the supplementary material (S1.3). Briefly, the aliquot reacted with the

120 ferrozine reagent and the reducing agent for $16 \mathrm{~h}$ under light conditions (to benefit from photoreduction; Anastácio et al., 2008) before being buffered at $\mathrm{pH} 9.5$ and reading the absorbance at $562 \mathrm{~nm}$. The method detection limit with a $1 \mathrm{~cm}$ light path was approximately $0.010 \mathrm{mg} \mathrm{Fe} \mathrm{L}^{-1}$ in solutions and $0.017 \mathrm{mg} \mathrm{Fe} \mathrm{L}^{-1}$ for digests.

\subsection{Sediment physicochemical analyses}

A sediment sample was dried at $104{ }^{\circ} \mathrm{C}$ to measure moisture content. Fresh sediment pH was measured in D.I. water at 1:5 125 sediment to solution ratio. We measured two common P sorption indices on fresh sediment: anion storage capacity (ASC; Blakemore et al., 1987) and the Bache-Williams index (BWI; Bache and Williams, 1971) as modified by Burkitt et al. (2002). 
https://doi.org/10.5194/bg-2019-400

Preprint. Discussion started: 18 October 2019

(c) Author(s) 2019. CC BY 4.0 License.

\section{(c) (i)}

Both are single-point isotherms with overnight shaking $(16 \mathrm{~h})$ but differ in their conditions. ASC uses solution that is buffered at $\mathrm{pH}$ of 4.6 with $1000 \mathrm{mg} \mathrm{P} \mathrm{L}^{-1}$ (1:5 sediment to solution ratio) and expressed as percent removal of P. BWI uses a $0.01 \mathrm{M}$ $\mathrm{CaCl}_{2}$ solution (no $\mathrm{pH}$ buffer) with $1000 \mathrm{mg} \mathrm{P} \mathrm{kg}^{-1}$ sediment added (here, $100 \mathrm{mg} \mathrm{P} \mathrm{L}^{-1}$ at sediment to solution ratio of 1:10)

130 and is expressed as $\mathrm{P}$ sorption (mg $\mathrm{P} \mathrm{kg}^{-1}$ sediment) divided by $\log _{10}\left(c_{e}\right)$ where $c_{e}$ is the remaining equilibrium solution concentration in $\mu \mathrm{g} \mathrm{P} \mathrm{L}^{-1}$. After centrifuging (2400 $\mathrm{g}$ for 15 minutes), the supernatants were analyzed for DRP via the molybdenum-blue method (Murphy and Riley, 1962).

A subsample of sediment was freeze-dried and analyzed for total $\mathrm{C}$ and $\mathrm{N}$ with a $\mathrm{CN}$ elemental analyzer and for total element concentrations with ICP-OES following microwave digestion with nitric acid plus hydrogen peroxide. Additionally, dried

135 sediment samples were sieved to $<1 \mathrm{~mm}$ and analyzed for particle size distributions via laser-diffraction, which are expressed on a percent volume basis (Eshel et al., 2004); here, we define clays as $\leq 4 \mu \mathrm{m}$, silt as $>4 \mu \mathrm{m}$ and $\leq 62.5 \mu \mathrm{m}$, and sands as $>$ $62.5 \mu \mathrm{m}$.

\subsection{Sediment phosphorus fractionation}

We began sediment $\mathrm{P}$ fractionation within a week of sampling using fresh (not dried) sediments (Simpson et al., 2019)

140 following the scheme of Jan et al. (2015). The primary details of the sequential fractionation are given here and in Table 1; further details are given in the supplementary material (S1). We used $0.5 \mathrm{~g}$ d.w. sediment and $10 \mathrm{~mL}$ of extractant in each step, in triplicate. The bicarbonate-dithionite (BD) solution (0.1 $\mathrm{M} \mathrm{NaHCO}_{3}$ and $0.1 \mathrm{M} \mathrm{Na}_{2} \mathrm{~S}_{2} \mathrm{O}_{4}, \mathrm{pH} 7.2$; BD-I and BD-II fractions) was prepared fresh with de-aerated D.I. water (subject to vacuum for $30 \mathrm{~min}$ ) and used immediately. The $\mathrm{NaOH}$ (I and II) and $\mathrm{HCl}$ fractions used $1 \mathrm{M} \mathrm{NaOH}$ and $0.5 \mathrm{M} \mathrm{HCl}$, respectively. A $0.5 \mathrm{M} \mathrm{NaCl}$ wash step was included after the BD-II and NaOH-

145 II steps to prevent carryover to the next fraction (Condron and Newman, 2011; Jensen and Thamdrup, 1993). Following the extraction at room temperature with an end-over-end shaker, we centrifuged (10 $\mathrm{min}$ at $2400 \mathrm{~g}$ ) and filtered the extracts (Whatman grade 41). The BD-I and NaOH-I fractions involved 5 min of shaking, immediate centrifuging, decanting, and a further 5 min extraction (i.e., 10 minute total extraction time) as per Jan et al. (2015).

We did not analyze DRP in the BD extracts due to analytical difficulty (Lukkari et al., 2007); however, we suspected little, if

150 any, organic $\mathrm{P}$ would contribute to the TP signal since BD primarily targets phosphate associated with reducible metal oxides (Jan et al., 2013; Jensen and Thamdrup, 1993). Although we used a colorimetric method suited for alkaline extracts (He and Honeycutt, 2005), RP concentrations in the $\mathrm{NaOH}$ fractions were likely compromised by silicates since the strong alkaline solution solubilizes silica minerals (Lindsay, 1979; Sauer et al., 2006) and silicate produces a molybdenum-blue complex analogous to phosphate (Nagul et al., 2015). However, NaOH-TP values are still valid since digestion removes the silicate

155 interference (Malá and Lagová, 2014; Zhang et al., 1999). Therefore, we restrict our discussion to NaOH-TP. Total P in the $\mathrm{BD}$ and $\mathrm{NaOH}$ fractions was determined via acid-persulfate autoclave digestion (method 4500-P; APHA, 2005) followed by the molybdenum-blue method (method detection limit of $\sim 0.02 \mathrm{mg} \mathrm{P} \mathrm{L}^{-1}$ for digests). More analytical details are in the supplementary material (S1.2). 
https://doi.org/10.5194/bg-2019-400

Preprint. Discussion started: 18 October 2019

(c) Author(s) 2019. CC BY 4.0 License.

(c) (i)

In addition to the $\mathrm{P}$ in each fraction, we measured total $\mathrm{Fe}$ in the $\mathrm{BD}$ and $\mathrm{NaOH}$ digests with the ferrozine method described above. We examined patterns in $\mathrm{Fe}$ and $\mathrm{P}$ contents among the $\mathrm{BD}$ and $\mathrm{NaOH}$ fractions with molar $\mathrm{Fe}: \mathrm{P}$ ratios. All fractionation data presented in this paper are based on the averages of the laboratory triplicate analyses.

\subsection{Geochemical equilibria}

We examined phosphate mineral equilibria with regard to streamwater chemistry to determine the direction of potential precipitation/dissolution reactions (Pierzynski et al., 2005). We employed the PHREEQC geochemical model (Parkhurst and Appelo, 2013) with the MINTEQA2 version 4 database to calculate mineral saturation indices (SIs) and therefore discuss saturation states with reference to the minerals (Appelo and Postma, 2005). A mineral's SI is defined as $\log _{10}\left(\mathrm{IAP} / \mathrm{K}_{\mathrm{sp}}\right.$ ), where IAP is the ion activity product measured in solution and $\mathrm{K}_{\mathrm{sp}}$ is the mineral's equilibrium solubility constant. A SI $>0$ and SI $<0$ indicate super- and subsaturation with respect to the mineral phase. We employ these data to detect if the thermodynamic equilibria favor precipitation reactions as a potential mechanism for DRP removal, but cannot determine what phases actually occur as there may be kinetic limitations (Plant and House, 2002; Stumm and Morgan, 1996). The analytical input data consisted of: stream temperature, $\mathrm{pH}$, total dissolved anions and cations, alkalinity, and DRP. Here, we assumed DRP to be primarily orthophosphate. Since these streams were above or near oxygen saturation at time of sampling, we assumed that $\mathrm{Fe}$ was in an oxidized state ( $\mathrm{Fe}(\mathrm{III}))$.

\subsection{Data and statistical methods}

175 Two sites in the sedimentary class - both at pristine, forested headwaters - had DRP concentrations below our detection limits. To mitigate potential bias, we inserted reference DRP values based on previous analyses for streams under the same classification within the REC (McDowell et al., 2013). Additionally, through exploratory analyses, we found it necessary to remove data with a spring-fed source of flow as a confounding variable when modelling DRP (see below). We hypothesized that the spring-fed streams had greatly diminished hyporheic exchange - thus limiting the interaction between sediment reaction sites and the water column. This limitation could be due to 1) accumulation of fine, silty sediments which restricted hydraulic conductivity (Aubeneau et al., 2014; Packman and Salehin, 2003; Weigelhofer et al., 2018), 2) low-gradients which limited hydrodynamic forces at the streambed (Boano et al., 2014), and 3) the likely presence of groundwater inputs along the reach, which are known to limit hyporheic exchange flows (Azizian et al., 2017).

We summarized differences between the stream and sediment variables (physico- and geochemical) between the three geology

185 classes with nonparametric tests (Hollander et al., 2013). We first tested the null hypothesis $\left(\mathrm{H}_{0}\right)$ that the locations of the groupwise distributions were equal via the Kruskal-Wallis test; if $\mathrm{H}_{0}$ was rejected, we then constructed multiple comparisons with rank statistics, adjusting for simultaneous inferences (Konietschke et al., 2012, 2015). Additionally, Spearman correlations were used to describe relationships between variables of interest. We explored the sediment-P attenuation mechanism in streams by fitting simple predictive models (Shmueli, 2010); we used robust linear models ("rlm" function in MASS package;

190 Venables and Ripley, 2002) to model DRP and sediment P sorption (see supplementary material; S2). All tests were performed 
https://doi.org/10.5194/bg-2019-400

Preprint. Discussion started: 18 October 2019

(c) Author(s) 2019. CC BY 4.0 License.

(c) (i)

at 95\% confidence and all analyses were conducted in R (version 3.5.2; R Core Team, 2018). The data can be found at Figshare (https://figshare.com/s/718226c7f1940d631755).

\section{Results}

\subsection{Stream water chemistry and mineral equilibria}

195 Stream physicochemistry at the time of sampling is summarized in Table 2 . The streams ranged from low to moderate alkalinity (16.7 to $88.8 \mathrm{mg} \mathrm{CaCO}_{3} \mathrm{~L}^{-1}$, mean of $42.7 \mathrm{mg} \mathrm{CaCO}_{3} \mathrm{~L}^{-1}$ ) and mean conductivity was $143 \mu \mathrm{S} \mathrm{cm}^{-1}$. For the time of sampling (generally, 1000 to $1600 \mathrm{~h}$ ), $\mathrm{pH}$ averaged 7.44 (6.43 to 7.93). Dissolved reactive P varied among geology classes with the lowest median DRP concentration in sedimentary, followed by alluvium, and then by volcanic basic (5.0, 7.4, and $27.7 \mu \mathrm{g} P$ $\mathrm{L}^{-1}$, respectively).

200 Stream geochemical equilibria modelling with PHREEQC was used to examine important mineral phases in the water column (Fig. 2). Stable, yet kinetically slow-to-form, $\mathrm{Al}$ and $\mathrm{Fe}$ minerals such as gibbsite and goethite were supersaturated in the water column; amorphous $\mathrm{Al}$ species $\left(\mathrm{Al}(\mathrm{OH})_{3}(\mathrm{am})\right)$ were subsaturated. The most reactive $\mathrm{Fe}$ species studied here, ferrihydrite $\left(\mathrm{Fe}(\mathrm{OH})_{3}(\mathrm{am})\right.$ ), was supersaturated (overall mean SI $1.9 \pm 0.6$ ), particularly over volcanic basic geologies (mean SI 2.9 \pm 0.2 ). We note that ferrihydrite SI correlated with log-activity of $\mathrm{HPO}_{4}{ }^{2-}(\rho=0.71, p<0.001)$. Further, $\mathrm{CaCO}_{3}$ precipitation was not

205 favorable (SI range of -2.1 to -0.08). Therefore, for these grab samples, $\mathrm{CaCO}_{3}$ co-precipitation of phosphate was not a likely mechanism.

Phosphate mineral solubilities were also investigated. The activities of phosphate and Fe/Al were too low to precipitate any $\mathrm{P}$ minerals from the water column in these streams (e.g., strengite; Fig. 2). For Ca-phosphate minerals, the less thermodynamically stable phases (e.g., $\left.\mathrm{CaHPO}_{4} \cdot\left(\mathrm{H}_{2} \mathrm{O}\right)_{2}\right)$ were sub-saturated in all samples. However, several streams showed

210 saturation to slight super-saturation with respect to hydroxylapatite; log-activity of $\mathrm{HPO}_{4}{ }^{2-}$ is plotted against a function of $\mathrm{Ca}^{2+}$ and $\mathrm{H}^{+}$activities with reference to the standard solubility curve of hydroxylapatite in Fig. 3. All three geologies had some waters with positive hydroxylapatite SIs but, notably, the saturation appears to not extend significantly past the hydroxylapatite solubility curve (max SI of 1.7). We noted no other geochemically significant relationships for other mineral SIs (Fig. S1) or ion log-activities (Fig. S2). Given that most phosphorous minerals of interest were sub-saturated in the water column, and that

215 hydroxylapatite likely requires greater SI values before actively precipitating (see discussion below), mineral precipitation does not seem a significant mechanism for P removal in these streams.

\subsection{General stream sediment physicochemistry}

Physicochemical characteristics of the benthic sediments are summarized in Table 3. The sediments were largely neutral (mean $\mathrm{pH}$ of 7.10). The fine sediments sampled in this survey were predominantly sandy (mean sand content of 84\%), although five alluvium sites and two volcanic basic sites had less than $80 \%$ sand content (silt + clay content range from 21 to $92 \%$ ). Sediments from spring-fed streams were much finer ( $\mathrm{D}_{50}$ of $\left.171 \pm 172 \mu \mathrm{m}\right)$ than those in hill-fed streams $(597 \pm 172 \mu \mathrm{m})$. The sediments 
https://doi.org/10.5194/bg-2019-400

Preprint. Discussion started: 18 October 2019

(c) Author(s) 2019. CC BY 4.0 License.

\section{(c) (i)}

were relatively low in total $\mathrm{C}$ (overall median of $3.0 \mathrm{~g} \mathrm{C} \mathrm{kg}^{-1}$ ) except for the spring sites (median of $20 \mathrm{~g} \mathrm{C} \mathrm{kg}^{-1}$ ). Owing to the different geological origins, the volcanic basic sediments were enriched with $\mathrm{Al}, \mathrm{Fe}, \mathrm{Mn}$, and $\mathrm{P}$ in comparison to the sedimentary and alluvium sediments.

\subsection{Stream sediment phosphorus and iron fractionation}

\subsubsection{Phosphorus fractionation}

Sediment $\mathrm{P}$ concentration fractionated according to the procedure by Jan et al. (2015) varied considerably by the catchment geology (Fig. 4). The most labile pool, $\mathrm{H}_{2} \mathrm{O}-\mathrm{P}$, was relatively high in the volcanic basic sediments (mean $\pm \mathrm{SD} ; 3.84 \pm 3.76$ $\left.\mathrm{mg} \mathrm{P} \mathrm{kg}{ }^{-1}\right)$ and alluvium sediments $\left(1.82 \pm 1.41 \mathrm{mg} \mathrm{P} \mathrm{kg}^{-1}\right)$, but lower for sedimentary sites $\left(0.44 \pm 0.08 \mathrm{mg} \mathrm{P} \mathrm{kg}^{-1}\right.$; Table 4). Both reductively-soluble sediment P pools, BD-I and BD-II, were enriched in alluvium and volcanic basic sediments in comparison to sedimentary sites, with total BD-extractable P (BD-I plus BD-II) of $84.3 \pm 84.1,77.6 \pm 26.7$, and $6.60 \pm 3.03$ $\mathrm{mg} \mathrm{P} \mathrm{kg}{ }^{-1}$, respectively. The mean proportion of the reductively-soluble sediment $\mathrm{P}$ pool attributed to amorphous Fe oxides (BD-I), rather than crystalline Fe oxides (BD-II), was $62 \%$ in alluvium sediments but evenly distributed in volcanic basic sediments (49\%). Both BD-I and BD-II P fractions correlated with fines (clays plus silts) concentration (respectively, $\rho=0.89$ and $0.84, p<0.001$ for both tests; Fig. S3). Further, the labile P pools of $\mathrm{H}_{2} \mathrm{O}-\mathrm{P}$ and BD-I P together comprised only 0.5 to $21 \%$ of total $\mathrm{P}$, with means of $1.0 \pm 0.5,8.2 \pm 6.7$, and $2.1 \pm 1.4 \%$ for the sedimentary, alluvium, and volcanic basic geologies, respectively.

The $\mathrm{NaOH}$-extractable $\mathrm{P}$ pool averaged $34.3 \pm 10.7,91.8 \pm 84.7$, and $518 \pm 329 \mathrm{mg} \mathrm{P} \mathrm{kg}^{-1}$ for sediments from the sedimentary, alluvium, and volcanic basic geologies, respectively. The more labile $\mathrm{NaOH}$ fraction ( $\mathrm{NaOH}-\mathrm{I})$ made up the majority of the total $\mathrm{NaOH}$-extractable $\mathrm{P}$ pool $(67-71 \%$ on average). Total $\mathrm{NaOH}$-extractable $\mathrm{P}$ correlated with $\mathrm{Al}$ content $(\rho=0.47, p=$ 0.008), but no other relationships (e.g., with total C) were evident. The least available sediment $\mathrm{P}$ pool analyzed, HCl-P, averaged 452 ( \pm 161$), 337( \pm 163)$, and $1373( \pm 572) \mathrm{mg} \mathrm{P} \mathrm{kg}^{-1}$ for sites in the sedimentary, alluvium, and volcanic basic geologies, respectively. As expected, HCl-P correlated strongly with $\mathrm{Ca}(\rho=0.84, p<0.001)$ and $\mathrm{Mg}$ content $(\rho=0.71, p<$ $0.001)$ since this fraction is dominated by primary mineral $P$.

245 In-stream DRP correlated well with both $\mathrm{H}_{2} \mathrm{O}-\mathrm{P}$ and the sum of $\mathrm{H}_{2} \mathrm{O}-\mathrm{P}$ and BD-I P (hereafter, labile P; Fig. 5). Using sediment $\mathrm{P}$ pools as the primary predictors for DRP in hill-fed streams (Table S2), the best-fit linear model employed geology and $\mathrm{H}_{2} \mathrm{O}-$

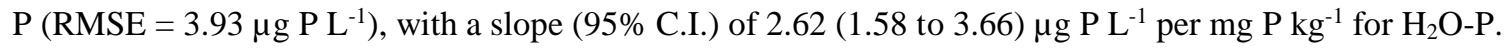

\subsubsection{Iron fractionation}

In addition to $\mathrm{P}$, we measured $\mathrm{Fe}$ in selected extracts of the $\mathrm{P}$ fractionation scheme (Fig. 6). Although total Fe is similar between alluvium and sedimentary sites (means of 22.0 and $23.4 \mathrm{~g} \mathrm{Fe} \mathrm{kg}^{-1}$; Table 3), reactive Fe pools varied markedly within and between all catchment geologies (Table 4). Total BD-extractable Fe was $2280( \pm 2200), 700( \pm 242)$, and $7710( \pm 2120) \mathrm{mg}$ $\mathrm{Fe} \mathrm{kg}^{-1}$ for the alluvium, sedimentary, and volcanic basic sites, respectively. On average, the amorphous Fe pool made up 52, 
https://doi.org/10.5194/bg-2019-400

Preprint. Discussion started: 18 October 2019

(c) Author(s) 2019. CC BY 4.0 License.

\section{(c) (i)}

38, and $34 \%$ of the BD-extractable Fe in alluvium, sedimentary, and volcanic basic sediments. The BD-extractable pools of Fe correlated with percent fines (Fig. S4), where Spearman $\rho$ was $0.87(\mathrm{p}<0.001)$ and $0.79(\mathrm{p}<0.001)$ for BD-I and BD-II, respectively. The Fe extracted by $\mathrm{NaOH}$ was at least one order of magnitude less than $\mathrm{BD}$-extractable $\mathrm{Fe}$ for each geology (totals of 59 to $\left.250 \mathrm{mg} \mathrm{Fe} \mathrm{kg}^{-1}\right)$; NaOH-I Fe related to percent fines $(\rho=0.77, \mathrm{p}<0.001)$ and total $\mathrm{C}(\rho=0.75, \mathrm{p}<0.001)$, which is likely due to release of Fe complexed with organic matter during extraction. In general, the BD- and $\mathrm{NaOH}$-extractable Fe scaled with total Fe $(\rho=0.45(p=0.012)$ and $\rho=0.39(p=0.033)$, respectively). However, reactive Fe contributed only a minor portion of total $\mathrm{Fe}$ in these sediments $(8.6 \pm 7.2 \%$ and $0.6 \pm 0.8 \%$ for total $\mathrm{BD}$ - and $\mathrm{NaOH}$-extractable $\mathrm{Fe}$, respectively; Fig. 6).

\subsubsection{Fe:P ratios in sediments}

Molar Fe:P in pools of sediment P varied depending on the pool and the catchment geology (Table 4, Fig. S5). In general, Fe:P ratios were much lower for the $\mathrm{NaOH}$ fractions (approximately 0.25 to $3 \mathrm{~mol} \mathrm{Fe} \mathrm{mol}^{-1}$ ) than for other fractions $(>13 \mathrm{~mol} \mathrm{Fe}$ mol $\mathrm{P}^{-1}$ ), likely due to little surface reactive Fe left after BD extraction while containing P bound with constituents other than

265 Fe. A paired Wilcoxon signed-rank test on Fe:P ratios in the BD fractions indicated that BD-II Fe:P is, on average, 25.6 (95\% C.I., 14.4 to 36.1) mol Fe mol P-1 greater than BD-I Fe:P. However, Fe:P ratios for either BD-I or BD-II fractions did not improve linear model fits for either DRP or ASC (data not shown). For the BD (I and II) fractions, median Fe:P was less in

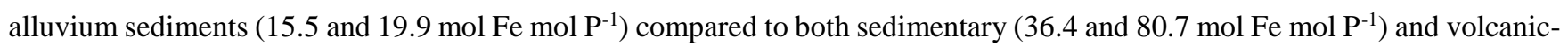

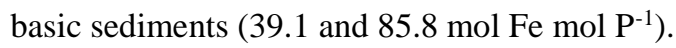

\subsection{Stream sediment phosphorus sorption}

Sediment $\mathrm{P}$ sorption metrics are summarized in Table 4. Although ASC (a measure of $\mathrm{P}$ retention at low pH) and BWI (P retention at neutral $\mathrm{pH}$ and controlled $\mathrm{Ca}$ concentration) differ in how $\mathrm{P}$ sorption potential is determined, a similar pattern was apparent in both variables for the three sampled geologies. Given the widespread use of ASC in soil classification (and management) in New Zealand (Saunders, 1965), we focus on ASC for brevity. The sedimentary samples had lower ASC (10.2 $\pm 5.6 \%)$ than either alluvium $(33.6 \pm 26.9 \%)$ or volcanic basic sediments $(49.4 \pm 11.1 \%)$. There was no clear relationship between ASC and sediment Fe:P ratios (Fig. S6), while ASC was correlated with BD-I ( $\rho=0.77, p<0.001)$, BD-II $(\rho=0.65$, $p<0.001)$, and total $\mathrm{Fe}(\rho=0.55, p=0.002)$ pools (Fig. 7).

More refractory pools of Fe were less predictive of ASC than BD-I Fe (Fig. 7). While ASC for the refractory Fe pools tended to cluster according to geology and stream source of flow, ASC varied linearly as a function of BD-I Fe (all data), which we illustrate with a linear modelling exercise, summarized in Table S3. The simple model of only BD-I Fe had the lowest AIC and the lowest RMSE (9.2\%); the estimated slope for BD-I Fe was 0.0174 (95\% C.I., 0.0152 to 0.0197 ) \% per mg Fe $\mathrm{kg}^{-1}$. Additionally, while adding catchment geology did not improve the model fit for BD-I Fe, both the BD-II and total Fe models included this term for their respective optimal models. Thus, BD-I Fe alone predicted ASC optimally and captured the variance otherwise provided by geology or refractory Fe to the lesser models. 
https://doi.org/10.5194/bg-2019-400

Preprint. Discussion started: 18 October 2019

(c) Author(s) 2019. CC BY 4.0 License.

(c) (i)

285 Contrary to our expectations, sediments with greater sorption potential positively correlated with in-stream DRP (Fig. 8), but only for the case of hill-fed streams. In addition to the linear models fitted with the labile P fractions above, we used ASC as a predictor of DRP (Table S2) - again, we excluded spring-fed sites as a confounding variable. Using ASC alone gave similar performance (RMSE of $4.44 \mu \mathrm{g} \mathrm{P} \mathrm{L}^{-1}$ ) as the models with terms for geology and the labile $\mathrm{P}$ fractions, but with less model degrees of freedom. Overall, the best linear model for DRP employed ASC and $\mathrm{H}_{2} \mathrm{O}-\mathrm{P}$ (RMSE of $4.38 \mu \mathrm{g} \mathrm{P} \mathrm{L}^{-1}$ ), with slopes of 2.03 (1.22 to 2.83) $\mu \mathrm{g} \mathrm{P} \mathrm{L}^{-1}$ per $\mathrm{mg} \mathrm{H}_{2} \mathrm{O}-\mathrm{P} \mathrm{kg}^{-1}$ and 0.325 (0.218 to 0.431$) \mu \mathrm{g} \mathrm{P} \mathrm{L}{ }^{-1}$ per ASC \%.

\section{Discussion}

Phosphorus in streams does not travel as a conservative solute. Our data suggests that bioavailable P, i.e., DRP and labile sediment $\mathrm{P}$ fractions, in these streams is likely to be modified by two principal factors: 1) reactive Fe content as derived from both geology and in-stream Fe cycling, and 2) the exchange between sediment porewaters and the water column (i.e., hyporheic exchange) as governed by hydraulic forces and sediment particle size distribution. We summarize our lines of evidence to support this hypothesis below.

\subsection{Stream water-column geochemistry and dissolved reactive phosphorus}

Catchment geology is a primary control on the geochemical composition of stream water (Bluth and Kump, 1994; Stumm and Morgan, 1996), and our results suggest that the Ca-based mechanisms for P removal were insignificant in our streams. Among the geochemical equilibria affecting phosphate in solution, phosphate-minerals rarely had the thermodynamic potential to form in these waters. The most stable phosphate mineral, hydroxylapatite, showed some cases of near-saturation (SI $\approx 0$; Fig. 3). However, empirical research has suggested that the required supersaturation for hydroxylapatite to significantly precipitate from solution is much higher (reported SI from 3 to 10; House, 1999; Plant and House, 2002; Sø et al., 2011). Therefore, hydroxylapatite and other phosphate-mineral precipitation seems, at best, a secondary mechanism for $\mathrm{P}$ removal in these streams. In contrast, streams with greater Ca concentrations (e.g., >100 $\mathrm{mg} \mathrm{Ca} \mathrm{L}^{-1}$ ) and $\mathrm{pH}(>8)$ will likely be more conducive for Ca-P mineral precipitation (Diaz et al., 1994). It is striking that some streams approach, but do not significantly extend beyond, the hydroxylapatite solubility curve, which could suggest a role for hydroxylapatite equilibrium. However, stream solution chemistry is more complex than ideal solutions modelled by PHREEQC, where even the solubility constant for hydroxylapatite is subject to considerable uncertainty (Golterman, 2004). In addition, other phosphate-minerals (e.g., various

$310 \mathrm{Al}$ and Fe based phosphate-minerals) are unlikely to contribute to phosphate activity in the water column, but may be more important in some subsurface environments (e.g., Denver et al., 2010; Rothe et al., 2014).

Since, calcite co-precipitates with phosphate (Golterman, 2004; House, 2003), periods of calcite precipitation in streams may provide an opportunity for phosphate removal, particularly in low-phosphate systems (Machesky et al., 2010; Plant and House, 2002; S $\varnothing$ et al., 2011). House (1999) suggested that calcite precipitation in streams becomes significant near SI $\approx 1$. In the 315 present study, however, we only observed negative SI's for calcite (Fig. 2). Our study design was more likely to capture the 
https://doi.org/10.5194/bg-2019-400

Preprint. Discussion started: 18 October 2019

(c) Author(s) 2019. CC BY 4.0 License.

\section{(c) (i)}

upper extent of calcite SI variability since: 1$)$ calcite saturation peaks during the day when photosynthesis depletes $\mathrm{CO}_{2}(\mathrm{~g})$ and increases pH (Nimick et al., 2011; Stets et al., 2017) and 2) calcite solubility decreases with greater temperatures during the day (Stumm and Morgan, 1996). It is likely that our study streams were not alkaline enough for significant calcite interactions (here, median alkalinities of 38.2 to 42.1 , maximum of $88.8 \mathrm{mg} \mathrm{L}^{-1}$ as $\mathrm{CaCO}_{3}$; maximum $\mathrm{pH}$ of 7.93; Table 2) since streams that reach a calcite $\mathrm{SI} \geq 1$ typically have alkalinity $>100 \mathrm{mg} \mathrm{L}^{-1}$ as $\mathrm{CaCO}_{3}$ and sustain $\mathrm{pH}>8$ (Corman et al., 2015; Neal et al., 2002; Nimick et al., 2011; Stets et al., 2017). Hence, we rule out calcite-phosphate co-precipitation as a significant mechanism for DRP removal in these streams.

The removal of $\mathrm{P}$ in streams via Ca-P mechanisms is frequently documented (Burns et al., 2015; Cohen et al., 2013; Jarvie et al., 2006), but such studies are located in catchments dominated by carbonaceous/karst geologies. Since many streams suffering from P pollution may not have such 'self-cleansing' mechanisms available, knowledge of other processes for P attenuation are critical for understanding $\mathrm{P}$ transport.

Aside from Ca-based solution geochemistry, an unexpected observation from this study was the supersaturation of ferrihydrite and its relationship with $\mathrm{HPO}_{4}{ }^{2-}$ activity (Fig. S1). Ferric iron is largely insoluble in most stream conditions (oxygenated water and $\mathrm{pH}$ near or above neutral) and $\mathrm{Fe}(\mathrm{II})$ would presumably be associated only with reducing zones within the stream corridor (Stumm and Sulzberger, 1992), thus positive ferrihydrite SI seems implausible. Fox (1988) explained the problem that, in most streams, dissolved $\mathrm{Fe}$ is overestimated because common filtration methods (i.e., $0.45 \mu \mathrm{m}$ filters) fail to remove colloidal $\mathrm{Fe}$ species (Baken et al., 2016b; van der Grift et al., 2014). Our apparent supersaturation with respect to ferrihydrite is within the range of previously observed over-estimates (SI up to 5 in most cases; Fox, 1988) and is a limitation of our dataset. However, the positive relation between ferrihydrite SI and DRP may indirectly point towards evidence of colloidal Fe species carrying sorbed phosphate and should be investigated in future research.

\subsection{Amount and form of sediment phosphorus depends on geology}

Given the enormous amounts of sediment that stream networks retain and the long timescales for its transit (Czuba et al., 2017; Wohl, 2015), P bound in benthic sediments represents a crucial component of legacy P. However, we found that most sediment $\mathrm{P}$ was unlikely to be bioavailable in our study streams (Fig. 4). Taking $\mathrm{H}_{2} \mathrm{O}$ and BD-I extractable $\mathrm{P}$ (labile $\mathrm{P}$ ) as potentially bioavailable in lotic systems and definitely available in receiving lentic systems (e.g., lakes; Golterman, 2004; Jan et al., 2015; Jensen and Thamdrup, 1993; Monbet et al., 2010), sediment labile P was generally <10\% of total P (maximum of $21 \%$ of total P), but varied with geology. Although small, these pools are highly reactive under baseflow and may be subjected to microbial turnover (McDowell, 2003), exchange with porewaters via desorption or reductive dissolution (Lewandowski and Nützmann, 2010; Parsons et al., 2017; Zak et al., 2006), and potentially to P-scavenging periphyton mats (Wood et al., 2015).

\section{$345 \quad 4.3$ Amorphous iron content determines sediment phosphorus sorption capacity}

Benthic sediment Fe has long been thought to provide much of the reactivity for P in streams (Danen-Louwerse et al., 1993; Froelich, 1988; Wauchope and McDowell, 1984). Therefore, we selected a fractionation scheme to target the responsible 
https://doi.org/10.5194/bg-2019-400

Preprint. Discussion started: 18 October 2019

(c) Author(s) 2019. CC BY 4.0 License.

\section{(c) $\underset{\mathrm{BY}}{\mathrm{BV}}$}

fractions of Fe. To our knowledge, our study is the first application of the sediment P fractionation scheme developed by Jan et al. (2015) to stream sediments. The motivation behind this fractionation scheme is that, in the absence of precipitation mechanisms, the more soluble, amorphous forms of $\mathrm{Fe}$ and $\mathrm{Al}$ oxides are the ones responsible for $\mathrm{P}$ retention and possible release (Jan et al., 2013, 2015; Postma, 1993). With this fractionation, we found large differences between catchment geologies and substrate texture (coarse sediments in hill-fed streams vs. silty sediments in spring-fed streams) in the amounts of reactive Fe (both BD-I and BD-II Fe) and its associated P, while total Fe was much less variable (Fig. 4 and Fig. 6). Further, BD-I Fe alone predicted sediment P sorption potential, as opposed to the more crystalline (BD-II) or refractory (total) Fe pools (Fig. 7, Table S3). Hence, we focus our discussion around BD-I Fe and its implications for stream P transport. The first BD step efficiently targets surface-reactive, amorphous Fe oxides, while the second BD step extracts more-crystalline, less reactive Fe oxides (Jan et al., 2015). This geochemical difference was evident in the Fe:P ratios (Table 4), where mean BD-I Fe:P ratios (varying with geology from $18.3 \pm 9.9$ to $65.0 \pm 66.9)$ were significantly lower than BD-II Fe:P $(31.6 \pm 25.1$ to $99.2 \pm 61$ ), owing to the greater affinity for $\mathrm{P}$ in the amorphous fraction. Pure Fe-P minerals would have much lower Fe:P ratios (e.g., 1 for $\mathrm{FePO}_{4}$ ); laboratory studies have observed molar Fe:P ratios of approximately 2 to 5 for $\mathrm{P}$ incorporated into Fe oxides during precipitation (Deng and Stumm, 1994; Senn et al., 2015) or adsorbed onto fresh Fe oxide precipitants (Lijklema, 1980). In their study, Senn et al. (2015) report that Fe(III) precipitants in environmental conditions similar to that within many streams and hyporheic zones (circumneutral $\mathrm{pH}$, varying amounts of $\mathrm{Ca}, \mathrm{PO}_{4}$, and silicate) are a complex mixture of basic $\left(\mathrm{Ca}-\mathrm{FePO}_{4}\right.$, ferrihydrite-type, and poorly crystalline lepidocrocite/goethite precipitants. This mixture of $\mathrm{Fe}(\mathrm{III})$ precipitants with varying stoichiometries and phosphate sorption capacities may explain the wide variance we observed in the BD-I Fe:P ratios. For the BD-II fraction, Fe:P may be related to the weathering status of the parent sediment material (Lair et al., 2009), as more crystalline Fe oxides become less sorptive for P. Total Fe:P is less meaningful (Jan et al., 2013), due to the varying contributions of $\mathrm{Fe}$ oxides to the total $\mathrm{Fe}$ and of other pools of $\mathrm{P}$ (e.g., $\mathrm{NaOH}$-extractable $\mathrm{P}$ ) to the total $\mathrm{P}$ (Hoffman et al., 2009; Machesky et al., 2010). Here, the contribution of BD-extractable Fe to the total Fe was generally <10\%, indicating that much sediment $\mathrm{Fe}$ can be unimportant to in-stream $\mathrm{P}$ cycling.

While the Fe:P ratios differentiated pools of Fe according to their geochemical affinity for P (BD-I vs. BD-II), Fe:P ratios were poor predictors of sediment $\mathrm{P}$ sorption, likely due to the variable composition of Fe species present in these pools (Herndon et al., 2019; Senn et al., 2015). This result contrasts with previous notions that Fe:P indicates available sorption sites (Coelho et al., 2004; Jensen et al., 1992; Kronvang et al., 2009). Rather than the Fe:P ratio, our data suggests that the mass of BD-I Fe alone was largely responsible for sediment P sorption (Fig. 7, Table S3). This result was consistent regardless of sediment texture, source of flow, or catchment geology. Notwithstanding the contribution of Al oxides to P sorption (Danen-Louwerse et al., 1993; Mendes et al., 2018), reactive Fe species (defined by varying methodologies) are strong predictors of P sorption in a variety of aquatic environments (Machesky et al., 2010; Zhang and Huang, 2007; Zhou et al., 2005). For example, Marton and Roberts (2014) and Herndon et al. (2019) found that the Bache-Williams index (BWI) was predicted by amorphous or reactive Fe oxide contents in peat, tundra, and marsh soils; these observations are matched by our findings in benthic stream 
https://doi.org/10.5194/bg-2019-400

Preprint. Discussion started: 18 October 2019

(c) Author(s) 2019. CC BY 4.0 License.

(c) (i)

sediments (Fig. 7). While these environments differ substantially, a similar theme is apparent regarding Fe-P relationships: where redox interfaces generate amorphous Fe oxides, there is a greater potential for $\mathrm{P}$ adsorption.

\subsection{The ability for sediments to influence dissolved reactive phosphorus depends on reactivity and connectivity}

The above discussion infers that reactive Fe oxides are efficient traps for P but in reality - due to the advective nature of the hyporheic zone and the high spatiotemporal variation in biogeochemistry - the Fe oxides themselves are likely transient (van der Grift et al., 2014; Runkel et al., 1999; Smolders et al., 2017). Our study suggests that DRP paradoxically tends to increase with P sorption potential (Fig. 8), but only for the hill-fed streams. We suspect that, given the P sorption potential in these streams was driven by amorphous Fe oxides (Fig. 7), the dynamics of Fe cycling may be coupled with DRP through: 1) dynamic precipitation and dissolution of Fe oxides and their bound P (Rhoton et al., 2002; Runkel et al., 1999; Smolders et al., 2017) and 2) the generation of Fe colloids at redox interfaces bearing P and elevating DRP (Baken et al., 2016a; Briggs et al., 2015; Gottselig et al., 2017; Ren and Packman, 2005). Both of these mechanisms are constrained for streams with little hyporheic exchange (e.g., the spring-fed streams in the present study; Boano et al., 2014). While we have indications of the former (Fig. 7 and Fig. 8) and latter (ferrihydrite SI correlation with $\mathrm{HPO}_{4}{ }^{2-}$ activity; Fig. S1) hypotheses, it is beyond the scope of our study to discuss these meaningfully.

395 Further research is needed to link the abiotic P exchange mechanisms we have discussed to the spatiotemporal DRP signal observed in the water column. While stream sediments are well-known to provide reaction sites for $\mathrm{P}$, little has been done to link these reaction sites in streams to $\mathrm{P}$ cycling in a mechanistic manner, i.e., by connecting these zones of reactivity to hydrological transport (Boano et al., 2014). We suggest that future research on stream P cycling avoids mono-causal interpretations (Kalbitz et al., 2017), and incorporates the multiple mechanisms - both biotic and abiotic - where relevant.

\section{Conclusions}

Water-column and sediment biogeochemistry changes with catchment geology in ways critical to P cycling. Low to moderate alkalinity (i.e., $<100 \mathrm{mg} \mathrm{L}^{-1}$ as $\mathrm{CaCO}_{3}$ ) streams had little potential to remove $\mathrm{P}$ via Ca-based (co-)precipitation mechanisms, making interactions with benthic sediments more important. We found sediment $\mathrm{P}$ sorption mechanisms captured within labile sediment $\mathrm{P}$ fractions $\left(\mathrm{H}_{2} \mathrm{O}\right.$ and $\mathrm{BD}-\mathrm{I}$ extractable $\left.\mathrm{P}\right)$ were likley linked to reactive Fe pools that comprised minor proportions 405 of the total Fe content. The amount of this labile sediment $\mathrm{P}$ was predominantly driven by the catchment geology. However, the data also suggested that labile P co-varied with DRP where hyporheic exchange likely mediated the interaction between the water column and porewaters in hill-fed streams, whose sediments were more permeable than those in spring-fed streams. Both geology and hyporheic exchange are integral to the attenuation of $\mathrm{P}$ in streams and, hence, will need to be accounted for if baseflow DRP concentrations are to be predicted and managed. 
https://doi.org/10.5194/bg-2019-400

Preprint. Discussion started: 18 October 2019

(c) Author(s) 2019. CC BY 4.0 License.

(c) (i)

\section{Data availability}

The data reported here are available at Figshare (https://figshare.com/s/718226c7f1940d631755). The REC geodatabase is available through the New Zealand Ministry for the Environment (https://data.mfe.govt.nz/data/).

\section{Author contribution}

Conceptualization: ZS and RM with support from LM. Funding acquisition: RM. Resources \& supervision: RM and LC.

415 Methodology: ZS, RM, and LC. Formal analysis: ZS with support from RM. Investigation, visualization \& original draft: ZS. All authors contributed to the review and final draft.

\section{Competing interests}

The authors declare that they have no conflict of interest.

\section{Acknowledgements}

420 We thank Julie Clark at University of Otago for analyzing sediments for particle size distributions; Lincoln University technical staff for providing laboratory needs and some analyses, particularly Roger Cresswell, Lynne Clucas, Leanne Hassall, Vicky Zhang, and Shiv Pokhrel; Florencia De Lucca Agrelo for field and lab assistance; Marion Des Roseaux, Yuan Li, David Rex, and Tihana Vujinovic for occasional support; and the Our Land and Water National Science Challenge for funding the study (contract C10X1507 from the Ministry of Business, Innovation and Employment). This manuscript benefitted from review by

425 Andrea Leptin. 
https://doi.org/10.5194/bg-2019-400

Preprint. Discussion started: 18 October 2019

(c) Author(s) 2019. CC BY 4.0 License.

(c) (i)

\section{References}

Anastácio, A. S., Harris, B., Yoo, H. I., Fabris, J. D. and Stucki, J. W.: Limitations of the ferrozine method for quantitative 430 assay of mineral systems for ferrous and total iron, Geochim. Cosmochim. Acta, 72(20), 5001-5008, doi:10.1016/j.gca.2008.07.009, 2008.

APHA: Standard Methods for the Examination of Water and Wastewater, 21st Edition., American Public Health Association., 2005.

Appelo, C. A. J. and Postma, D.: Geochemistry, groundwater and pollution, 2nd ed., A.A. Balkema Publishers, Leiden, The 435 Netherlands., 2005.

Aubeneau, A. F., Hanrahan, B., Bolster, D. and Tank, J. L.: Substrate size and heterogeneity control anomalous transport in small streams, Geophys. Res. Lett., 41(23), 8335-8341, doi:10.1002/2014GL061838, 2014.

Azizian, M., Boano, F., Cook, P. L. M., Detwiler, R. L., Rippy, M. A. and Grant, S. B.: Ambient groundwater flow diminishes nitrate processing in the hyporheic zone of streams, Water Resour. Res., 53, doi:10.1002/2016WR020048.Received, 2017.

440 Bache, B. and Williams, E.: A phosphate sorption index for soil, Eur. J. Soil Sci., 22(3), 289-301, doi:10.1111/j.13652389.1971.tb01617.x, 1971.

Baken, S., Regelink, I. C., Comans, R. N. J., Smolders, E. and Koopmans, G. F.: Iron-rich colloids as carriers of phosphorus in streams: A field-flow fractionation study, Water Res., 99, 83-90, doi:10.1016/j.watres.2016.04.060, 2016a.

Baken, S., Moens, C., van der Grift, B. and Smolders, E.: Phosphate binding by natural iron-rich colloids in streams, Water

Res., 98, 326-333, doi:10.1016/j.watres.2016.04.032, 2016b.

Biggs, B. J. F.: Eutrophication of streams and rivers: dissolved nutrient-chlorophyll relationships for benthic algae, J. N. Am. Benthol. Soc., 19(1), 17-31, doi:10.2307/1468279, 2000.

Blakemore, L. C., Searle, P. L. and Daly, B. K.: Methods for chemical analysis of soils, NZ Soil Bureau Scientific Report 80., 1987.

450 Bluth, G. J. S. and Kump, L. R.: Lithologic and climatologic controls of river chemistry, Geochim. Cosmochim. Acta, 58(10), 2341-2359, doi:10.1016/0016-7037(94)90015-9, 1994.

Boano, F., Harvey, J. W., Marion, A., Packman, A. I., Revelli, R., Ridolfi, L. and Wörman, A.: Hyporheic flow and transport processes: Mechanisms, models, and bioghemical implications, Rev. Geophys., 52, 603-679, doi:10.1002/2012RG000417.Received, 2014.

455 Briggs, M. A., Day-Lewis, F. D., Zarnetske, J. P. and Harvey, J. W.: A physical explanation for the development of redox microzones in hyporheic flow, Geophys. Res. Lett., 42(11), 4402-4410, doi:10.1002/2015GL064200, 2015.

Brown, L. J.: Canterbury, in Groundwaters of New Zealand, pp. 441-459, New Zealand Hydrological Society Inc., Wellington, New Zealand., 2001.

Burkitt, L. L., Moody, P. W., Gourley, C. J. P. and Hannah, M. C.: A simple phosphorus buffering index for Australian soils,

Soil Res., 40(3), 497-513, doi:10.1071/sr01050, 2002. 
https://doi.org/10.5194/bg-2019-400

Preprint. Discussion started: 18 October 2019

(c) Author(s) 2019. CC BY 4.0 License.

(c) (i)

Burns, E. E., Comber, S., Blake, W., Goddard, R. and Couldrick, L.: Determining riverine sediment storage mechanisms of biologically reactive phosphorus in situ using DGT, Environ Sci Pollut Res, 22(13), 9816-9828, doi:10.1007/s11356-0154109-3, 2015.

Coelho, J. P., Flindt, M. R., Jensen, H. S., Lillebø, A. I. and Pardal, M. A.: Phosphorus speciation and availability in intertidal sediments of a temperate estuary: relation to eutrophication and annual P-fluxes, Estuarine Coastal Shelf Sci., 61(4), 583-590, doi:10.1016/j.ecss.2004.07.001, 2004.

Cohen, M. J., Kurz, M. J., Heffernan, J. B., Martin, J. B., Douglass, R. L., Foster, C. R. and Thomas, R. G.: Diel phosphorus variation and the stoichiometry of ecosystem metabolism in a large spring-fed river, Ecol. Monogr., 83(2), 155-176, doi:10.1890/12-1497.1, 2013.

470 Condron, L. M. and Newman, S.: Revisiting the fundamentals of phosphorus fractionation of sediments and soils, J Soils Sediments, 11(5), 830-840, doi:10.1007/s11368-011-0363-2, 2011.

Corman, J. R., Moody, E. K. and Elser, J. J.: Stoichiometric impact of calcium carbonate deposition on nitrogen and phosphorus supplies in three montane streams, Biogeochemistry, 126(3), 285-300, doi:10.1007/s10533-015-0156-6, 2015.

Czuba, J. A., Foufoula-Georgiou, E., Gran, K. B., Belmont, P. and Wilcock, P. R.: Interplay between spatially-explicit sediment sourcing, hierarchical river-network structure, and in-channel bed-material sediment transport and storage dynamics, J. Geophys. Res. Earth Surf., 1-31, doi:10.1002/2016JF003965, 2017.

Danen-Louwerse, H., Lijklema, L. and Coenraats, M.: Iron content of sediment and phosphate adsorption properties, Hydrobiol., 253(1), 311-317, 1993.

D'Angelo, E., Crutchfield, J. and Vandiviere, M.: Rapid, sensitive, microscale determination of phosphate in water and soil,

J. Environ. Qual., 30(6), 2206-2209, doi:10.2134/jeq2001.2206, 2001.

Davies, J.-M. and Bothwell, M. L.: Responses of lotic periphyton to pulses of phosphorus: P-flux controlled growth rate, Freshwater Biol., 57(12), 2602-2612, doi:10.1111/fwb.12032, 2012.

Demars, B. O. L.: Whole-stream phosphorus cycling: Testing methods to assess the effect of saturation of sorption capacity on nutrient uptake length measurements, Water Res., 42(10-11), 2507-2516, doi:10.1016/j.watres.2008.02.010, 2008.

485 Deng, Y. and Stumm, W.: Reactivity of aquatic iron(III) oxyhydroxides-implications for redox cycling of iron in natural waters, Appl. Geochem., 9(1), 23-36, doi:10.1016/0883-2927(94)90049-3, 1994.

Denver, J. M., Cravotta, C. A., Ator, S. W. and Lindsey, B. D.: Contributions of phosphorus from groundwater to streams in the Piedmont, Blue Ridge, and Valley and Ridge physiographic provinces, eastern United States, U.S. Geological Survey, Reston, Va., 2010.

490 Diaz, O. A., Reddy, K. R. and Moore, P. A.: Solubility of inorganic phosphorus in stream water as influenced by $\mathrm{pH}$ and calcium concentration, Water Res., 28(8), 1755-1763, doi:10.1016/0043-1354(94)90248-8, 1994.

Dupas, R., Minaudo, C., Gruau, G., Ruiz, L. and Gascuel-Odoux, C.: Multidecadal trajectory of riverine nitrogen and phosphorus dynamics in rural catchments, Water Resour. Res., 54(8), 5327-5340, doi:10.1029/2018WR022905, $2018 \mathrm{a}$.

Dupas, R., Tittel, J., Jordan, P., Musolff, A. and Rode, M.: Non-domestic phosphorus release in rivers during low-flow:

Mechanisms and implications for sources identification, J. Hydrol., 560, 141-149, doi:10.1016/j.jhydrol.2018.03.023, 2018b. 
https://doi.org/10.5194/bg-2019-400

Preprint. Discussion started: 18 October 2019

(c) Author(s) 2019. CC BY 4.0 License.

(c) (i)

Ensign, S. H. and Doyle, M. W.: Nutrient spiraling in streams and river networks, J. Geophys. Res. Biogeosci., 111(G4), doi:10.1029/2005JG000114, 2006.

Eshel, G., Levy, G. J., Mingelgrin, U. and Singer, M. J.: Critical evaluation of the use of laser diffraction for particle-size distribution analysis, Soil Sci. Soc. Am. J., 68(3), 736-743, doi:10.2136/sssaj2004.7360, 2004.

500 Fox, L. E.: The solubility of colloidal ferric hydroxide and its relevance to iron concentrations in river water, Geochim. Cosmochim. Acta, 52(3), 771-777, doi:10.1016/0016-7037(88)90337-7, 1988.

Froelich, P. N.: Kinetic control of dissolved phosphate in natural rivers and estuaries: A primer on the phosphate buffer mechanism, Limnol. Oceanogr., 33(4.2), 649-668, 1988.

Gérard, F.: Clay minerals, iron/aluminum oxides, and their contribution to phosphate sorption in soils - A myth revisited,

Geoderma, 262, 213-226, doi:10.1016/j.geoderma.2015.08.036, 2016.

Goldberg, S. and Sposito, G.: A chemical model of phosphate adsorption by soils: I. Reference oxide minerals, Soil Sci. Soc. Am. J., 48(4), 772-778, doi:10.2136/sssaj1984.03615995004800040015x, 1984.

Golterman, H. L.: The calcium- and iron bound phosphate phase diagram, Hydrobiol., 159(2), 149-151, doi:10.1007/BF00014722, 1988.

510 Golterman, H. L.: The chemistry of phosphate and nitrogen compounds in sediments, Kluwer Academic Publishers, Dordrecht, The Netherlands., 2004.

Gottselig, N., Amelung, W., Kirchner, J. W., Bol, R., Eugster, W., Granger, S. J., Hernández-Crespo, C., Herrmann, F., Keizer, J. J., Korkiakoski, M., Laudon, H., Lehner, I., Löfgren, S., Lohila, A., Macleod, C. J. A., Mölder, M., Müller, C., Nasta, P., Nischwitz, V., Paul-Limoges, E., Pierret, M. C., Pilegaard, K., Romano, N., Sebastià, M. T., Stähli, M., Voltz, M., Vereecken,

515 H., Siemens, J. and Klumpp, E.: Elemental composition of natural nanoparticles and fine colloids in European forest stream waters and their role as phosphorus carriers, Global Biogeochem. Cycles, 31(10), 1592-1607, doi:10.1002/2017GB005657, 2017.

Gran, G.: Determination of the equivalence point in potentiometric titrations. Part II, Analyst, 77(920), 661-671, doi:10.1039/AN9527700661, 1952.

520 Griffiths, N. A. and Johnson, L. T.: Influence of dual nitrogen and phosphorus additions on nutrient uptake and saturation kinetics in a forested headwater stream, Freshw. Sci., 000-000, doi:10.1086/700700, 2018.

van der Grift, B., Rozemeijer, J. C., Griffioen, J. and van der Velde, Y.: Iron oxidation kinetics and phosphate immobilization along the flow-path from groundwater into surface water, Hydrol. Earth Syst. Sci., 18(11), 4687-4702, doi:https://doi.org/10.5194/hess-18-4687-2014, 2014.

525 Haggard, B. E. and Sharpley, A. N.: Phosphorus transport in streams: Processes and modeling considerations, in Modeling phosphorus in the environment, CRC Press, Boca Raton, FL., 2007.

Haggard, B. E., Stanley, E. H. and Storm, D. E.: Nutrient retention in a point-source-enriched stream, J. N. Am. Benthol. Soc., 24(1), 29-47, doi:10.1899/0887-3593(2005)024<0029:NRIAPS>2.0.CO;2, 2005.

Hall, R. O., Bernhardt, E. S. and Likens, G. E.: Relating nutrient uptake with transient storage in forested mountain streams,

Limnol. Oceanogr., 47(1), 255-265, doi:10.4319/1o.2002.47.1.0255, 2002. 
https://doi.org/10.5194/bg-2019-400

Preprint. Discussion started: 18 October 2019

(c) Author(s) 2019. CC BY 4.0 License.

\section{(c) (1)}

Hall, R. O., Baker, M. A., Rosi-Marshall, E. J., Tank, J. L. and Newbold, J. D.: Solute-specific scaling of inorganic nitrogen and phosphorus uptake in streams, Biogeosciences, 10(11), 7323-7331, doi:https://doi.org/10.5194/bg-10-7323-2013, 2013.

Halliday, S. J., Wade, A. J., Skeffington, R. A., Neal, C., Reynolds, B., Rowland, P., Neal, M. and Norris, D.: An analysis of long-term trends, seasonality and short-term dynamics in water quality data from Plynlimon, Wales, Sci. Total Environ., 434,

186-200, doi:10.1016/j.scitotenv.2011.10.052, 2012.

Harvey, J. W.: Hydrologic exchange flows and their ecological consequences in river corridors, in Stream Ecosystems in a Changing Environment, pp. 1-84, Academic Press, London, UK., 2016.

He, Z. and Honeycutt, C. W.: A modified molybdenum blue method for orthophosphate determination suitable for investigating enzymatic hydrolysis of organic phosphates, Commun. Soil Sci. Plant Anal., 36(9-10), 1373-1383, doi:10.1081/CSS-200056954, 2005.

Herndon, E. M., Kinsman-Costello, L., Duroe, K. A., Mills, J., Kane, E. S., Sebestyen, S. D., Thompson, A. A. and Wullschleger, S. D.: Iron (oxyhydr)oxides serve as phosphate traps in tundra and boreal peat soils, J. Geophys. Res. Biogeosci., 124, doi:10.1029/2018JG004776, 2019.

Hill, W. R., Fanta, S. E. and Roberts, B. J.: Quantifying phosphorus and light effects in stream algae, Limnol. Oceanogr., 54(1), 368-380, doi:10.4319/lo.2009.54.1.0368, 2009.

Hoffman, A. R., Armstrong, D. E., Lathrop, R. C. and Penn, M. R.: Characteristics and influence of phosphorus accumulated in the bed sediments of a stream located in an agricultural watershed, Aquat. Geochem., 15(3), 371-389, doi:10.1007/s10498008-9043-2, 2009.

Hollander, M., Wolfe, D. A. and Chicken, E.: The one-way layout, in Nonparametric Statistical Methods, pp. 39-114, John Wiley \& Sons., 2013.

House, W. A.: The physico-chemical conditions for the precipitation of phosphate with calcium, Environ. Technol., 20(7), 727-733, doi:10.1080/09593332008616867, 1999.

House, W. A.: Geochemical cycling of phosphorus in rivers, Appl. Geochem., 18(5), 739-748, doi:10.1016/S08832927(02)00158-0, 2003.

555 Huang, H., Wang, Z., Chen, D., Xia, F., Shang, X., Liu, Y., Dahlgren, R. A. and Mei, K.: Influence of land use on the persistence effect of riverine phosphorus, Hydrol. Processes, 32(1), 118-125, doi:10.1002/hyp.11408, 2018.

Jan, J., Borovec, J., Kopáček, J. and Hejzlar, J.: What do results of common sequential fractionation and single-step extractions tell us about $\mathrm{P}$ binding with $\mathrm{Fe}$ and $\mathrm{Al}$ compounds in non-calcareous sediments?, Water Res., 47(2), 547-557, doi:10.1016/j.watres.2012.10.053, 2013.

560 Jan, J., Borovec, J., Kopáček, J. and Hejzlar, J.: Assessment of phosphorus associated with Fe and Al (hydr)oxides in sediments and soils, J. Soils Sediments, 15(7), 1620-1629, doi:10.1007/s11368-015-1119-1, 2015.

Jarvie, H. P., Withers, P. J. A. and Neal, C.: Review of robust measurement of phosphorus in river water: sampling, storage, fractionation and sensitivity, Hydrol. Earth Syst. Sci., 6(1), 113-131, doi:10.5194/hess-6-113-2002, 2002.

Jarvie, H. P., Jürgens, M. D., Williams, R. J., Neal, C., Davies, J. J. L., Barrett, C., White, J., Jarvie, H. P., Ju, M. D., Davies, 565 J. J. L., Barrett, C. and White, J.: Role of river bed sediments as sources and sinks of phosphorus across two major eutrophic 
https://doi.org/10.5194/bg-2019-400

Preprint. Discussion started: 18 October 2019

(c) Author(s) 2019. CC BY 4.0 License.

(c) (i)

UK river basins: the Hampshire Avon and Herefordshire Wye, J. Hydrol., 304(1), 51-74, doi:10.1016/j.jhydrol.2004.10.002, 2005 .

Jarvie, H. P., Neal, C., Jürgens, M. D., Sutton, E. J., Neal, M., Wickham, H. D., Hill, L. K., Harman, S. A., Davies, J. J. L., Warwick, A., Barrett, C., Griffiths, J., Binley, A., Swannack, N. and McIntyre, N.: Within-river nutrient processing in Chalk streams: The Pang and Lambourn, UK, J. Hydrol., 330(1), 101-125, doi:10.1016/j.jhydrol.2006.04.014, 2006.

Jarvie, H. P., Sharpley, A. N., Scott, J. T., Haggard, B. E., Bowes, M. J. and Massey, L. B.: Within-river phosphorus retention: accounting for a missing piece in the watershed phosphorus puzzle, Environ. Sci. Technol., 46(24), 13284-13292, doi:10.1021/es303562y, 2012.

Jensen, H. S. and Thamdrup, B.: Iron-bound phosphorus in marine sediments as measured by bicarbonate-dithionite extraction,

in Proceedings of the Third International Workshop on Phosphorus in Sediments, edited by P. C. M. Boers, Th. E. Cappenberg, and W. van Raaphorst, pp. 47-59, Springer Netherlands., 1993.

Jensen, H. S., Kristensen, P., Jeppesen, E. and Skytthe, A.: Iron:phosphorus ratio in surface sediment as an indicator of phosphate release from aerobic sediments in shallow lakes, in Sediment/Water Interactions, edited by B. T. Hart and P. G. Sly, pp. 731-743, Springer Netherlands., 1992.

580 Kalbitz, K., Kaiser, K. and McDowell, W. H.: Nitrate decline unlikely to have triggered release of dissolved organic carbon and phosphate to streams, Global Change Biol., 23(7), 2535-2536, doi:10.1111/gcb.13659, 2017.

Konietschke, F., Hothorn, L. A. and Brunner, E.: Rank-based multiple test procedures and simultaneous confidence intervals, Electron. J. Statist., 6, 738-759, doi:10.1214/12-EJS691, 2012.

Konietschke, F., Placzek, M., Schaarschmidt, F. and Hothorn, L. A.: nparcomp: An R software package for nonparametric

multiple comparisons and simultaneous confidence intervals, J. Stat. Software, 64(1), 1-17, doi:10.18637/jss.v064.i09, 2015.

Kronvang, B., Hoffmann, C. C. and Dröge, R.: Sediment deposition and net phosphorus retention in a hydraulically restored lowland river floodplain in Denmark: combining field and laboratory experiments, Mar. Freshwater Res., 60(7), 638-646, doi:10.1071/MF08066, 2009.

Lair, G. J., Zehetner, F., Khan, Z. H. and Gerzabek, M. H.: Phosphorus sorption-desorption in alluvial soils of a young weathering sequence at the Danube River, Geoderma, 149(1-2), 39-44, doi:10.1016/j.geoderma.2008.11.011, 2009.

Lewandowski, J. and Nützmann, G.: Nutrient retention and release in a floodplain's aquifer and in the hyporheic zone of a lowland river, Ecol. Eng., 36(9), 1156-1166, doi:10.1016/j.ecoleng.2010.01.005, 2010.

Lijklema, L.: Interaction of orthophosphate with iron(III) and aluminum hydroxides, Environ. Sci. Technol., 14(5), 537-541, doi:10.1021/es60165a013, 1980.

Lindsay, W. L.: Chemical equilibria in soils., John Wiley and Sons Ltd., 1979.

Lukkari, K., Hartikainen, H. and Leivuori, M.: Fractionation of sediment phosphorus revisited. I: Fractionation steps and their biogeochemical basis, Limnol. Oceanogr. Methods, 5(12), 433-444, doi:10.4319/lom.2007.5.433, 2007.

Machesky, M. L., Holm, T. R. and Slowikowski, J. A.: Phosphorus Speciation in Stream Bed Sediments from an Agricultural Watershed: Solid-Phase Associations and Sorption Behavior, Aquat Geochem, 16(4), 639-662, doi:10.1007/s10498-0109103-2, 2010. 
https://doi.org/10.5194/bg-2019-400

Preprint. Discussion started: 18 October 2019

(c) Author(s) 2019. CC BY 4.0 License.

(c) (i)

Malá, J. and Lagová, M.: Comparison of digestion methods for determination of total phosphorus in river sediments, Chem. Pap., 68(8), 1015-1021, doi:10.2478/s11696-014-0555-5, 2014.

Marton, J. M. and Roberts, B. J.: Spatial variability of phosphorus sorption dynamics in Louisiana salt marshes, J. Geophys. Res. Biogeosci., 119(3), 451-465, doi:10.1002/2013JG002486, 2014.

605 McCrackin, M. L., Muller-Karulis, B., Gustafsson, B. G., Howarth, R. W., Humborg, C., Svanbäck, A. and Swaney, D. P.: A century of legacy phosphorus dynamics in a large drainage basin, Global Biogeochem. Cycles, 32(7), 1107-1122, doi:10.1029/2018GB005914, 2018.

McDaniel, M. D., David, M. B. and Royer, T. V.: Relationships between benthic sediments and water column phosphorus in Illinois streams., J. Environ. Qual., 38(2), 607-617, doi:10.2134/jeq2008.0094, 2009.

610 McDowell, R. W.: Sediment phosphorus chemistry and microbial biomass along a lowland New Zealand stream, Aquat. Geochem., 9(1), 19-40, doi:10.1023/B:AQUA.0000005620.15485.6d, 2003.

McDowell, R. W.: Relationship between sediment chemistry, equilibrium phosphorus concentrations, and phosphorus concentrations at baseflow in rivers of the New Zealand National River Water Quality Network, J. Environ. Qual., 44(3), 921929, doi:10.2134/jeq2014.08.0362, 2015.

615 McDowell, R. W., Biggs, B. J. F., Sharpley, A. N. and Nguyen, L.: Connecting phosphorus loss from agricultural landscapes to surface water quality, Chem. Ecol., 20(1), 1-40, doi:10.1080/02757540310001626092, 2004.

McDowell, R. W., Snelder, T. H., Cox, N., Booker, D. J. and Wilcock, R. J.: Establishment of reference or baseline conditions of chemical indicators in New Zealand streams and rivers relative to present conditions, Mar. Freshwater Res., 64(5), 387400, doi:10.1071/MF12153, 2013.

620 McDowell, R. W., Cox, N., Daughney, C. J., Wheeler, D. and Moreau, M.: A national assessment of the potential linkage between soil, and surface and groundwater concentrations of phosphorus, J. Am. Water Resour. Assoc., 51(4), 992-1002, doi:10.1111/1752-1688.12337, 2015.

McDowell, R. W., Simpson, Z. P., Stenger, R. and Depree, C.: The influence of a flood event on the potential sediment control of baseflow phosphorus concentrations in an intensive agricultural catchment, J Soils Sediments, 19(1), 429-438, doi:10.1007/s11368-018-2063-7, 2019.

Meals, D. W., Dressing, S. A. and Davenport, T. E.: Lag time in water quality response to best management practices: a review, J. Environ. Qual., 39(1), 85-96, doi:10.2134/jeq2009.0108, 2010.

Mendes, L. R. D., Tonderski, K. and Kjaergaard, C.: Phosphorus accumulation and stability in sediments of surface-flow constructed wetlands, Geoderma, 331, 109-120, doi:10.1016/j.geoderma.2018.06.015, 2018.

630 Monbet, P., D. McKelvie, I. and J. Worsfold, P.: Sedimentary pools of phosphorus in the eutrophic Tamar estuary (SW England), J. Environ. Monit., 12(1), 296-304, doi:10.1039/B911429G, 2010.

Mulholland, P. J., Marzolf, E. R., Webster, J. R., Hart, D. R. and Hendricks, S. P.: Evidence that hyporheic zones increase heterotrophic metabolism and phosphorus uptake in forest streams, Limnol. Oceanogr., 42(3), 443-451, doi:10.4319/lo.1997.42.3.0443, 1997.

635 Murphy, J. and Riley, J. P.: A modified single solution method for the determination of phosphate in natural waters, Anal. Chim. Acta, 27, 31-36, doi:10.1016/S0003-2670(00)88444-5, 1962. 
https://doi.org/10.5194/bg-2019-400

Preprint. Discussion started: 18 October 2019

(c) Author(s) 2019. CC BY 4.0 License.

\section{(c) (1)}

Muscarella, M. E., Bird, K. C., Larsen, M. L., Placella, S. A. and Lennon, J. T.: Phosphorus resource heterogeneity in microbial food webs, Aquat. Microb. Ecol., 73(3), 259-272, 2014.

Nagul, E. A., McKelvie, I. D., Worsfold, P. and Kolev, S. D.: The molybdenum blue reaction for the determination of orthophosphate revisited: Opening the black box, Anal. Chim. Acta, 890, 60-82, doi:10.1016/j.aca.2015.07.030, 2015.

Neal, C., Jarvie, H. P., Williams, R. J., Neal, M., Wickham, H. and Hill, L.: Phosphorus-calcium carbonate saturation relationships in a lowland chalk river impacted by sewage inputs and phosphorus remediation: an assessment of phosphorus self-cleansing mechanisms in natural waters, Sci. Total Environ., 282-283, 295-310, doi:10.1016/S0048-9697(01)00920-2, 2002 .

645 Newbold, J. D., Elwood, J. W., O’Neill, R. V. and Sheldon, A. L.: Phosphorus dynamics in a woodland stream ecosystem: a study of nutrient spiralling, Ecology, 64(5), 1249-1265, 1983.

Nimick, D. A., Gammons, C. H. and Parker, S. R.: Diel biogeochemical processes and their effect on the aqueous chemistry of streams: A review, Chem. Geol., 283(1), 3-17, doi:10.1016/j.chemgeo.2010.08.017, 2011.

Ohno, T. and Zibilske, L. M.: Determination of low concentrations of phosphorus in soil extracts using malachite green, Soil

Sci. Soc. Am. J., 55, 892-895, 1991.

Packman, A. I. and Salehin, M.: Relative roles of stream flow and sedimentary conditions in controlling hyporheic exchange, Hydrobiol., 494, 291-297, doi:10.1023/A:1025403424063, 2003.

Parfitt, R. L.: Anion Adsorption by Soils and Soil Materials, in Advances in Agronomy, vol. 30, edited by N. C. Brady, pp. 150, Academic Press., 1979.

655 Parkhurst, D. L. and Appelo, C. A. J.: Description of input and examples for PHREEQC version 3: a computer program for speciation, batch-reaction, one-dimensional transport, and inverse geochemical calculations, USGS Numbered Series, U.S. Geological Survey, Reston, VA. [online] Available from: http://pubs.er.usgs.gov/publication/tm6A43 (Accessed 9 November 2018), 2013.

Parsons, C. T., Rezanezhad, F., O'Connell, D. W. and Cappellen, P. V.: Sediment phosphorus speciation and mobility under dynamic redox conditions, Biogeosciences, 14(14), 3585-3602, doi:https://doi.org/10.5194/bg-14-3585-2017, 2017.

Pierzynski, G. M., McDowell, R. W. and Sims, J. T.: Chemistry, Cycling, and Potential Movement of Inorganic Phosphorus in Soils, in Phosphorus: Agriculture and the Environment, pp. 53-86, American Society of Agronomy, Madison, WI., 2005.

Plant, L. J. and House, W. A.: Precipitation of calcite in the presence of inorganic phosphate, Colloids Surf., A, 203(1), 143153, doi:10.1016/S0927-7757(01)01089-5, 2002.

665 Postma, D.: The reactivity of iron oxides in sediments: A kinetic approach, Geochim. Cosmochim. Acta, 57(21), 5027-5034, doi:10.1016/S0016-7037(05)80015-8, 1993.

Powers, S. M., Bruulsema, T. W., Burt, T. P., Chan, N. I., Elser, J. J., Haygarth, P. M., Howden, N. J. K., Jarvie, H. P., Lyu, Y., Peterson, H. M., Sharpley, A. N., Shen, J., Worrall, F. and Zhang, F.: Long-term accumulation and transport of anthropogenic phosphorus in three river basins, Nat. Geosci., 9(5), 353-356, doi:10.1038/ngeo2693, 2016.

670 R Core Team: R: A language and environment for statistical computing, R Foundation for Statistical Computing, Vienna, Austria. [online] Available from: https://ww.r-project.org/, 2018. 
https://doi.org/10.5194/bg-2019-400

Preprint. Discussion started: 18 October 2019

(c) Author(s) 2019. CC BY 4.0 License.

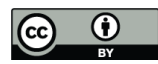

Ren, J. and Packman, A. I.: Coupled stream-subsurface exchange of colloidal hematite and dissolved zinc, copper, and phosphate, Environ. Sci. Technol., 39(17), 6387-6394, doi:10.1021/es050168q, 2005.

Rhoton, F. E., Bigham, J. M. and Lindbo, D. L.: Properties of iron oxides in streams draining the Loess Uplands of Mississippi, Appl. Geochem., 17(4), 409-419, doi:10.1016/S0883-2927(01)00112-3, 2002.

Rothe, M., Frederichs, T., Eder, M., Kleeberg, A. and Hupfer, M.: Evidence for vivianite formation and its contribution to long-term phosphorus retention in a recent lake sediment: a novel analytical approach, Biogeosciences, 11(18), 5169-5180, doi:https://doi.org/10.5194/bg-11-5169-2014, 2014.

Rounds, S. A.: Alkalinity and acid neutralizing capacity, in National field manual for the collection of water-quality data, vol. 680 9, edited by F. D. Wilde and D. B. Radtke, pp. 1-45, U.S. Geological Survey, Reston, Virginia. [online] Available from: https://water.usgs.gov/owq/FieldManual/Chapter6/section6.6/, 2012.

Runkel, R. L., Kimball, B. A., McKnight, D. M. and Bencala, K. E.: Reactive solute transport in streams: A surface complexation approach for trace metal sorption, Water Resour. Res., 35(12), 3829-3840, doi:10.1029/1999WR900259, 1999.

Sauer, D., Saccone, L., Conley, D. J., Herrmann, L. and Sommer, M.: Review of methodologies for extracting plant-available and amorphous Si from soils and aquatic sediments, Biogeochemistry, 80(1), 89-108, doi:10.1007/s10533-005-5879-3, 2006.

Saunders, W. M. H.: Phosphate retention by New Zealand soils and its relationship to free sesquioxides, organic matter, and other soil properties, N. Z. J. Agric. Res., 8(1), 30-57, doi:10.1080/00288233.1965.10420021, 1965.

Senn, A.-C., Kaegi, R., Hug, S. J., Hering, J. G., Mangold, S. and Voegelin, A.: Composition and structure of Fe(III)precipitates formed by $\mathrm{Fe}(\mathrm{II})$ oxidation in water at near-neutral $\mathrm{pH}$ : Interdependent effects of phosphate, silicate and Ca, Geochim. Cosmochim. Acta, 162, 220-246, doi:10.1016/j.gca.2015.04.032, 2015.

Sharpley, A., Jarvie, H. P., Buda, A., May, L., Spears, B. and Kleinman, P.: Phosphorus legacy: Overcoming the effects of past management practices to mitigate future water quality impairment, J. Environ. Qual., 42(5), 1308-1326, doi:10.2134/jeq2013.03.0098, 2013.

Shmueli, G.: To Explain or to Predict?, Statist. Sci., 25(3), 289-310, doi:10.1214/10-STS330, 2010.

695 Simpson, Z. P., McDowell, R. W. and Condron, L. M.: The error in stream sediment phosphorus fractionation and sorption properties effected by drying pretreatments, J Soils Sediments, 19(3), 1587-1597, doi:10.1007/s11368-018-2180-3, 2019.

Smolders, E., Baetens, E., Verbeeck, M., Nawara, S., Diels, J., Verdievel, M., Peeters, B., De Cooman, W. and Baken, S.: Internal loading and redox cycling of sediment iron explain reactive phosphorus concentrations in lowland rivers, Environ. Sci. Technol., 51(5), 2584-2592, doi:10.1021/acs.est.6b04337, 2017.

700 Snelder, T. H. and Biggs, B. J. F.: Multiscale river environment classification for water resources management, J. Am. Water Resour. Assoc., 38(5), 1225-1239, doi:10.1111/j.1752-1688.2002.tb04344.x, 2002.

Sø, H. U., Postma, D., Jakobsen, R. and Larsen, F.: Sorption of phosphate onto calcite; results from batch experiments and surface complexation modeling, Geochim. Cosmochim. Acta, 75(10), 2911-2923, doi:10.1016/j.gca.2011.02.031, 2011.

Stets, E. G., Butman, D., McDonald, C. P., Stackpoole, S. M., DeGrandpre, M. D. and Striegl, R. G.: Carbonate buffering and 705 metabolic controls on carbon dioxide in rivers, Global Biogeochem. Cycles, 31(4), 663-677, doi:10.1002/2016GB005578, 2017. 
https://doi.org/10.5194/bg-2019-400

Preprint. Discussion started: 18 October 2019

(c) Author(s) 2019. CC BY 4.0 License.

(c) (i)

Stookey, L. L.: Ferrozine - a New Spectrophotometric Reagent for Iron, Anal. Chem., 42(7), 779-, doi:10.1021/ac60289a016, 1970.

Stumm, W. and Morgan, J. J.: Aquatic Chemistry: Chemical Equilibria and Rates in Natural Waters, Third., John Wiley \& Sons, New York., 1996.

Stumm, W. and Sulzberger, B.: The cycling of iron in natural environments: Considerations based on laboratory studies of heterogeneous redox processes, Geochim. Cosmochim. Acta, 56(8), 3233-3257, doi:10.1016/0016-7037(92)90301-X, 1992.

Stutter, M. I., Demars, B. O. L. L. and Langan, S. J.: River phosphorus cycling: Separating biotic and abiotic uptake during short-term changes in sewage effluent loading, Water Res., 44(15), 4425-4436, doi:10.1016/j.watres.2010.06.014, 2010.

715 Venables, W. N. and Ripley, B. D.: Modern applied statistics with S-PLUS, Fourth., Springer, New York. [online] Available from: http://www.stats.ox.ac.uk/pub/MASS4, 2002.

Viollier, E., Inglett, P. W., Hunter, K., Roychoudhury, a N. and Van Cappellen, P.: The ferrozine method revisited: $\mathrm{Fe}$ (II)/Fe (III) determination in natural waters, Appl. Geochem., 15(6), 785-790, doi:10.1016/S0883-2927(99)00097-9, 2000.

Wauchope, R. D. and McDowell, L. L.: Adsorption of phosphate, arsenate, methanearsonate, and cacodylate by lake and 720 stream sediments: Comparisons with soils, J. Environ. Qual., 13(3), 499-504, doi:10.2134/jeq1984.00472425001300030034x, 1984.

Weigelhofer, G., Ramião, J. P., Pitzl, B., Bondar-Kunze, E. and O'Keeffe, J.: Decoupled water-sediment interactions restrict the phosphorus buffer mechanism in agricultural streams, Sci. Total Environ., 628-629, 44-52, doi:10.1016/j.scitotenv.2018.02.030, 2018.

725 Wohl, E.: Legacy effects on sediments in river corridors, Earth Sci. Rev., 147, 30-53, doi:10.1016/j.earscirev.2015.05.001, 2015 .

Wood, S. A., Depree, C., Brown, L., McAllister, T. and Hawes, I.: Entrapped sediments as a source of phosphorus in epilithic cyanobacterial proliferations in low nutrient rivers, PLOS ONE, 10(10), e0141063, doi:10.1371/journal.pone.0141063, 2015.

Zak, D., Kleeberg, A. and Hupfer, M.: Sulphate-mediated phosphorus mobilization in riverine sediments at increasing sulphate

730 concentration, River Spree, NE Germany, Biogeochemistry, 80(2), 109-119, doi:10.1007/s10533-006-0003-x, 2006.

Zhang, J. Z. and Huang, X. L.: Relative importance of solid-phase phosphorus and iron on the sorption behavior of sediments, Environ. Sci. Technol., 41(8), 2789-2795, doi:10.1021/es061836q, 2007.

Zhang, J. Z., Fischer, C. J. and Ortner, P. B.: Optimization of performance and minimization of silicate interference in continuous flow phosphate analysis, Talanta, 49(2), 293-304, doi:10.1016/S0039-9140(98)00377-4, 1999.

735 Zhou, A., Tang, H. and Wang, D.: Phosphorus adsorption on natural sediments: Modeling and effects of pH and sediment composition, Water Res., 39(7), 1245-1254, doi:10.1016/j.watres.2005.01.026, 2005. 
https://doi.org/10.5194/bg-2019-400

Preprint. Discussion started: 18 October 2019

(c) Author(s) 2019. CC BY 4.0 License.

(c) (i)

Table 1. Experimental procedure of the sequential sediment $P$ fractionation, following the method of Jan et al. (2015); the targeted 740 biogeochemical pools of $P$ are given, but are not exact since fractionation methods are operationally defined. $P$ and $F e$ analyses in the $\mathrm{BD}$ and $\mathrm{NaOH}$ fractions refer to total $\mathrm{P}$ and $\mathrm{Fe} . \dagger$ Not applicable

\begin{tabular}{|c|c|c|c|c|}
\hline Step or fraction & Solution & $\begin{array}{l}\text { Extraction } \\
\text { Time }\end{array}$ & Analyses & Primary biogeochemical pool \\
\hline 1. $\mathrm{H}_{2} \mathrm{O}$ & D.I. water & $30 \mathrm{~min}$ & $\mathrm{P}$ & Labile, loosely-bound P \\
\hline 2. BD-I & $\begin{array}{l}\text { Bicarbonate- } \\
\text { dithionite }\end{array}$ & $5+5 \min$ & $\mathrm{P}, \mathrm{Fe}$ & $\begin{array}{l}\text { Less-crystalline, surface-active } \mathrm{Fe} \\
\text { oxides }\end{array}$ \\
\hline 3. BD-II & $\begin{array}{l}\text { Bicarbonate- } \\
\text { dithionite }\end{array}$ & $2 \mathrm{~h}$ & $\mathrm{P}, \mathrm{Fe}$ & Crystalline, poorly active $\mathrm{Fe}$ oxides \\
\hline Wash & $\mathrm{NaCl}$ & $5 \mathrm{~min}$ & $\mathrm{NA}^{\dagger}$ & NA \\
\hline 4. $\mathrm{NaOH}-\mathrm{I}$ & $\mathrm{NaOH}$ & $5+5 \min$ & $\mathrm{P}, \mathrm{Fe}$ & $\begin{array}{l}\text { Active Al oxides, labile organic } \\
\text { matter, clay minerals }\end{array}$ \\
\hline 5. NaOH-II & $\mathrm{NaOH}$ & $16 \mathrm{~h}$ & $\mathrm{P}, \mathrm{Fe}$ & $\begin{array}{l}\text { Crystalline } \mathrm{Al} \text { oxides, refractory } \\
\text { organic matter, clay minerals }\end{array}$ \\
\hline Wash & $\mathrm{NaCl}$ & $5 \mathrm{~min}$ & NA & NA \\
\hline 6. $\mathrm{HCl}$ & $\mathrm{HCl}$ & $24 \mathrm{~h}$ & $\mathrm{P}$ & Primary minerals \\
\hline
\end{tabular}


https://doi.org/10.5194/bg-2019-400

Preprint. Discussion started: 18 October 2019

(c) Author(s) 2019. CC BY 4.0 License.

(c) (i)

Table 2. Summary of stream water chemistry grouped by River Environment Classification geology class; values are given as 745 medians (means \pm standard deviation); lowercase letter exponents represent group-wise comparisons between geology classes ( confidence level $=0.95$ ) .

\begin{tabular}{|c|c|c|c|c|}
\hline & & \multicolumn{3}{|c|}{ Geology Class } \\
\hline & Units & $\begin{array}{l}\text { Alluvium } \\
(n=15)\end{array}$ & $\begin{array}{l}\text { Sedimentary } \\
\qquad(n=10)\end{array}$ & $\begin{array}{l}\text { Volcanic basic } \\
\qquad(n=6)\end{array}$ \\
\hline pH & S.U. & $7.29^{\mathrm{a}}(7.26 \pm 0.33)$ & $7.54^{\mathrm{b}}(7.61 \pm 0.22)$ & $7.62^{b}(7.62 \pm 0.06)$ \\
\hline Conductivity & $\mu \mathrm{S} \mathrm{cm}{ }^{-1}$ & $142(154 \pm 51)$ & $78(121 \pm 79)$ & $155(152 \pm 18)$ \\
\hline Alkalinity & $\begin{array}{c}\mathrm{mg} \mathrm{L}^{-1} \text { as } \\
\mathrm{CaCO}_{3}\end{array}$ & $42.1(44.3 \pm 11.6)$ & $31.4(42.9 \pm 23.8)$ & $39.4(38.2 \pm 6.8)$ \\
\hline DRP & $\mu \mathrm{g} \mathrm{L}^{-1}$ & $7.4^{\mathrm{b}}(10.8 \pm 7.6)$ & $5.0^{\mathrm{a}}(5.6 \pm 2.8)$ & $27.7^{c}(26.9 \pm 11.3)$ \\
\hline $\mathrm{NO}_{3}-\mathrm{N}$ & $m g L^{-1}$ & $1.947^{\mathrm{b}}(1.857 \pm 1.22)$ & $0.111^{\mathrm{a}}(0.626 \pm 1.18)$ & $0.152^{\mathrm{a}}(0.151 \pm 0.080)$ \\
\hline $\mathrm{SO}_{4}$ & $m g L^{-1}$ & $8.21^{\mathrm{b}}(8.44 \pm 2.77)$ & $4.89^{b}(9.38 \pm 7.44)$ & $3.54^{\mathrm{a}}(3.49 \pm 0.55)$ \\
\hline Dissolved Fe & $\mathrm{mg} \mathrm{L}^{-1}$ & $0.011^{\mathrm{a}}(0.06 \pm 0.139)$ & $0.011^{\mathrm{a}}(0.012 \pm 0.006)$ & $0.137^{\mathrm{b}}(0.153 \pm 0.069)$ \\
\hline Dissolved Ca & $\mathrm{mg} \mathrm{L}^{-1}$ & $18.1^{\mathrm{b}}(18.3 \pm 5.52)$ & $11.9^{b}(17.09 \pm 9.8)$ & $8.9^{a}(8.79 \pm 1.33)$ \\
\hline
\end{tabular}


Table 3. Select physicochemical properties of the stream benthic sediments grouped by River Environment Classification geology class; $D_{50}$ is the median particle size of the fine sediments $(<2 \mathrm{~mm})$; values are given as medians (means \pm standard deviation); lower case letter exponents represent group-wise comparisons between geology classes $($ confidence level $=0.95)$.

\begin{tabular}{|c|c|c|c|c|}
\hline & & \multicolumn{3}{|c|}{ Geology Class } \\
\hline & Units & $\begin{array}{l}\text { Alluvium } \\
(n=15)\end{array}$ & $\begin{array}{c}\text { Sedimentary } \\
\qquad(n=10)\end{array}$ & $\begin{array}{l}\text { Volcanic basic } \\
\qquad(n=6)\end{array}$ \\
\hline pH & S.U. & $6.93^{\mathrm{a}}(6.91 \pm 0.24)$ & $7.12^{\mathrm{ab}}(7.26 \pm 0.46)$ & $7.26^{\mathrm{b}}(7.31 \pm 0.26)$ \\
\hline Total C & $\mathrm{g} \mathrm{kg}^{-1}$ & $3.68^{\mathrm{b}}(13.2 \pm 17.9)$ & $1.06^{\mathrm{a}}(1.3 \pm 0.58)$ & $8.53^{\mathrm{b}}(10.8 \pm 5.9)$ \\
\hline Total N & $\mathrm{g} \mathrm{kg}^{-1}$ & $0.41^{\mathrm{b}}(1.31 \pm 1.69)$ & $0.20^{\mathrm{a}}(0.23 \pm 0.12)$ & $0.65^{\mathrm{b}}(0.83 \pm 0.43)$ \\
\hline Total Al & $\mathrm{g} \mathrm{kg}^{-1}$ & $20.15^{\mathrm{a}}(21.93 \pm 6.04)$ & $18.44^{\mathrm{a}}(20.42 \pm 4.88)$ & $35.39^{\mathrm{b}}(37.2 \pm 8.35)$ \\
\hline Total Ca & $\mathrm{g} \mathrm{kg}^{-1}$ & $5.77^{\mathrm{a}}(6.25 \pm 2.34)$ & $5.97^{\mathrm{ab}}(6.35 \pm 2.21)$ & $9.59^{b}(9.46 \pm 2.14)$ \\
\hline Total Fe & $\mathrm{g} \mathrm{kg}^{-1}$ & $22.14^{\mathrm{a}}(21.95 \pm 4.05)$ & $23.31^{\mathrm{a}}(23.44 \pm 3.36)$ & $48.45^{\mathrm{b}}(50.43 \pm 5.93)$ \\
\hline Total Mn & $\mathrm{mg} \mathrm{kg}^{-1}$ & $379^{a}(455 \pm 275)$ & $372^{\mathrm{a}}(368 \pm 89.2)$ & $725^{b}(713 \pm 160)$ \\
\hline Total P & $\mathrm{mg} \mathrm{kg}^{-1}$ & $548^{a}(597 \pm 219)$ & $476^{\mathrm{a}}(462 \pm 121)$ & $2130^{\mathrm{b}}(2220 \pm 525)$ \\
\hline Clay & $\%$ volume & $0.011^{\mathrm{b}}(0.99 \pm 1.6)$ & $0^{\mathrm{a}}(0.001 \pm 0.004)$ & $0.3^{b}(0.5 \pm 0.7)$ \\
\hline Silt & $\%$ volume & $5.25^{\mathrm{b}}(19.8 \pm 25.9)$ & $0.049^{\mathrm{a}}(0.98 \pm 1.54)$ & $14.7^{\mathrm{b}}(16.8 \pm 9.96)$ \\
\hline Sand & $\%$ volume & $94.7^{\mathrm{a}}(79.2 \pm 27.4)$ & $99.9^{\mathrm{b}}(99.0 \pm 1.55)$ & $85.0^{\mathrm{a}}(82.7 \pm 10.7)$ \\
\hline D50 & $\mu \mathrm{m}$ & $415^{\mathrm{a}}(356 \pm 255)$ & $701^{b}(680 \pm 232)$ & $544^{\mathrm{ab}}(491 \pm 238)$ \\
\hline
\end{tabular}


Table 4. Stream sediment $P$ fractions, Fe fractions, molar Fe:P ratios (including total Fe to total $P$ ), and sorption metrics. Values are given as medians (means \pm standard deviation). The lowercase letter exponents represent group-wise comparisons between geology classes (confidence level $=\mathbf{0 . 9 5}$ ); for explanation of the sorption metrics, see Sect. 2.

\section{Geology Class}

\begin{tabular}{|c|c|c|c|c|}
\hline & Units & $\begin{array}{l}\text { Alluvium } \\
\qquad(n=15)\end{array}$ & $\begin{array}{l}\text { Sedimentary } \\
\qquad(n=10)\end{array}$ & $\begin{array}{l}\text { Volcanic basic } \\
\qquad(n=6)\end{array}$ \\
\hline \multicolumn{5}{|c|}{ Sediment $P$ fractions } \\
\hline $\mathrm{H}_{2} \mathrm{O}$ & \multirow{6}{*}{$\mathrm{mg} \mathrm{P} \mathrm{kg}{ }^{-1}$} & $1.39^{\mathrm{b}}(1.82 \pm 1.41)$ & $0.417^{\mathrm{a}}(0.436 \pm 0.081)$ & $2.48^{b}(3.84 \pm 3.76)$ \\
\hline BD-I & & $27.8^{b}(52.1 \pm 51.9)$ & $4.14^{\mathrm{a}}(3.62 \pm 1.87)$ & $31.8^{b}(40.4 \pm 25.5)$ \\
\hline BD-II & & $14.8^{b}(32.2 \pm 32.6)$ & $3.53^{\mathrm{a}}(2.98 \pm 1.405)$ & $38.4^{\mathrm{b}}(37.2 \pm 4.52)$ \\
\hline NaOH-I & & $39.4^{b}(61.2 \pm 60.3)$ & $25.2^{\mathrm{a}}(23.8 \pm 7.11)$ & $292^{c}(342 \pm 185)$ \\
\hline NaOH-II & & $20.2^{\mathrm{ab}}(30.6 \pm 29.1)$ & $10.5^{\mathrm{a}}(10.4 \pm 4.79)$ & $97.2^{\mathrm{b}}(176 \pm 177)$ \\
\hline $\mathrm{HCl}$ & & $271^{\mathrm{a}}(337 \pm 163)$ & $414^{\mathrm{ab}}(452 \pm 161)$ & $1400^{\mathrm{b}}(1370 \pm 572)$ \\
\hline \multicolumn{5}{|c|}{ Sediment $\mathrm{Fe}$ fractions } \\
\hline BD-I & \multirow{4}{*}{$\mathrm{mg} \mathrm{Fe} \mathrm{kg}{ }^{-1}$} & $529^{b}(1360 \pm 1500)$ & $252^{\mathrm{a}}(254 \pm 66.1)$ & $2480^{c}(2560 \pm 623)$ \\
\hline BD-II & & $664^{\mathrm{a}}(915 \pm 930)$ & $433^{a}(446 \pm 190)$ & $5990^{\mathrm{b}}(5150 \pm 1670)$ \\
\hline NaOH-I & & $50.4^{b}(92.98 \pm 102)$ & $21.7^{\mathrm{a}}(22.6 \pm 8.18)$ & $107^{\mathrm{c}}(118 \pm 41.6)$ \\
\hline NaOH-II & & $447^{b}(122 \pm 182)$ & $35.9^{\mathrm{a}}(36.2 \pm 11.1)$ & $99.6^{\mathrm{b}}(131 \pm 94.6)$ \\
\hline \multicolumn{5}{|c|}{ Fe:P (molar) } \\
\hline BD-I & \multirow{5}{*}{ mol Fe mol P-1 } & $15.5^{\mathrm{a}}(18.3 \pm 9.85)$ & $36.4^{\mathrm{b}}(65.01 \pm 66.9)$ & $39.1^{b}(40.6 \pm 14.3)$ \\
\hline BD-II & & $19.9^{\mathrm{a}}(31.6 \pm 25.05)$ & $80.7^{b}(99.2 \pm 61.01)$ & $85.8^{b}(76.6 \pm 21.6)$ \\
\hline NaOH-I & & $0.71^{\mathrm{a}}(1.15 \pm 1.15)$ & $0.52^{b}(0.59 \pm 0.34)$ & $0.23^{b}(0.25 \pm 0.15)$ \\
\hline NaOH-II & & $2.11(2.69 \pm 2.40)$ & $1.80(2.47 \pm 1.63)$ & $0.38(3.12 \pm 6.25)$ \\
\hline Total & & $22.3^{\mathrm{b}}(22.2 \pm 5.73)$ & $28.4^{\mathrm{c}}(29.1 \pm 4.25)$ & $13.3^{\mathrm{a}}(13.1 \pm 2.64)$ \\
\hline \multicolumn{5}{|c|}{ Sorption metrics } \\
\hline ASC & $\% \mathrm{P}$ retention & $14.3^{\mathrm{b}}(33.6 \pm 26.9)$ & $6.98^{\mathrm{a}}(10.2 \pm 5.58)$ & $49.4^{\mathrm{b}}(49.4 \pm 11.1)$ \\
\hline BWI & $\frac{\mathrm{mg} \mathrm{P} \mathrm{kg}}{\log _{10}\left(\mu g \mathrm{P} \mathrm{L}^{-1}\right)}$ & $12.7^{\mathrm{b}}(51.95 \pm 54.7)$ & $6.84^{\mathrm{a}}(8.8 \pm 5.57)$ & $53.5^{\mathrm{b}}(53.4 \pm 12.3)$ \\
\hline
\end{tabular}


https://doi.org/10.5194/bg-2019-400

Preprint. Discussion started: 18 October 2019

(c) Author(s) 2019. CC BY 4.0 License.
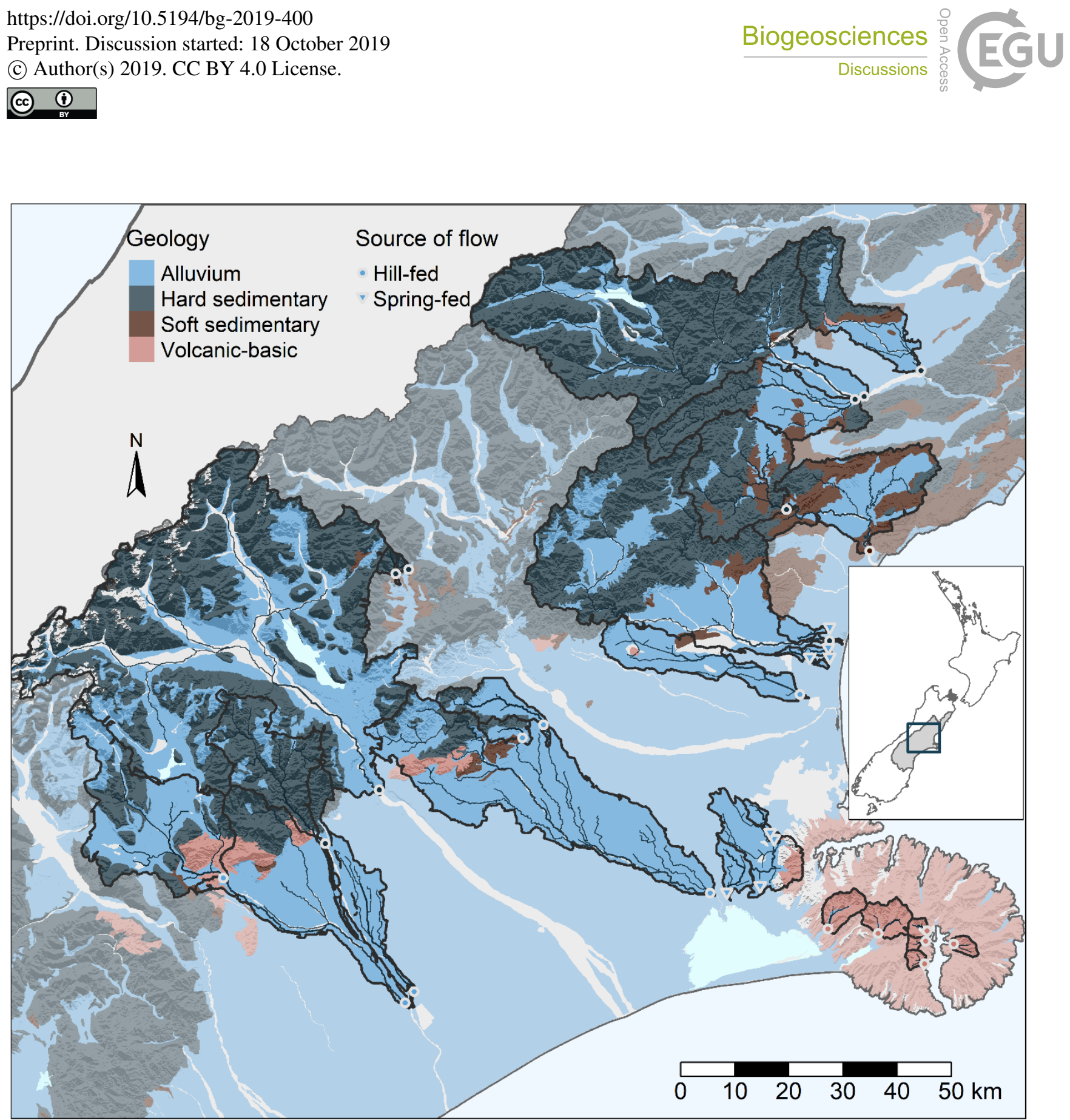

760 Figure 1. Study streams, and their catchments, in Canterbury, New Zealand (see inset). The geology classification used by the (New Zealand) River Environment Classification scheme is shown, with 'Miscellaneous' (loess, peat), 'Other' (river beds, ice cover, lakes, and urban centers), and Plutonic geology classes excluded for clarity. Sampling locations are shown, with circles indicating 'Hillfed' streams (i.e., no major groundwater inputs) and triangles indicating 'spring-fed' streams. 


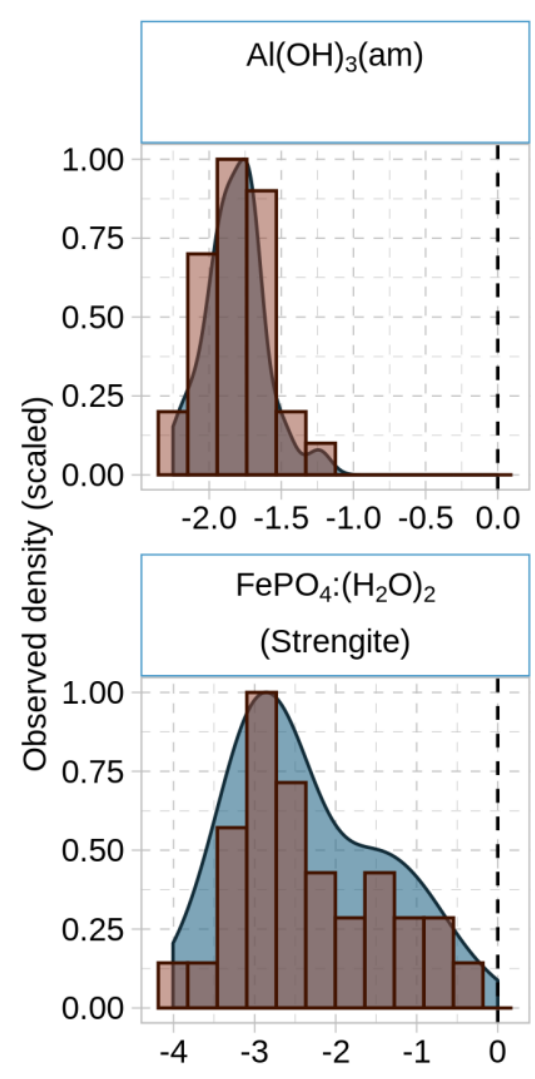

Figure 2. Distributions of select mineral saturation indices for the stream samples $(n=31)$, where positive (negative) saturation index (SI) indicates the thermodynamic potential for the mineral to precipitate (dissolve). The frequency distributions are displayed as normalized densities. SI=0 is indicated on each sub-plot with a dashed vertical line. The solid phase chemical formulae are provided as given in the MINTEQ.v4 database.
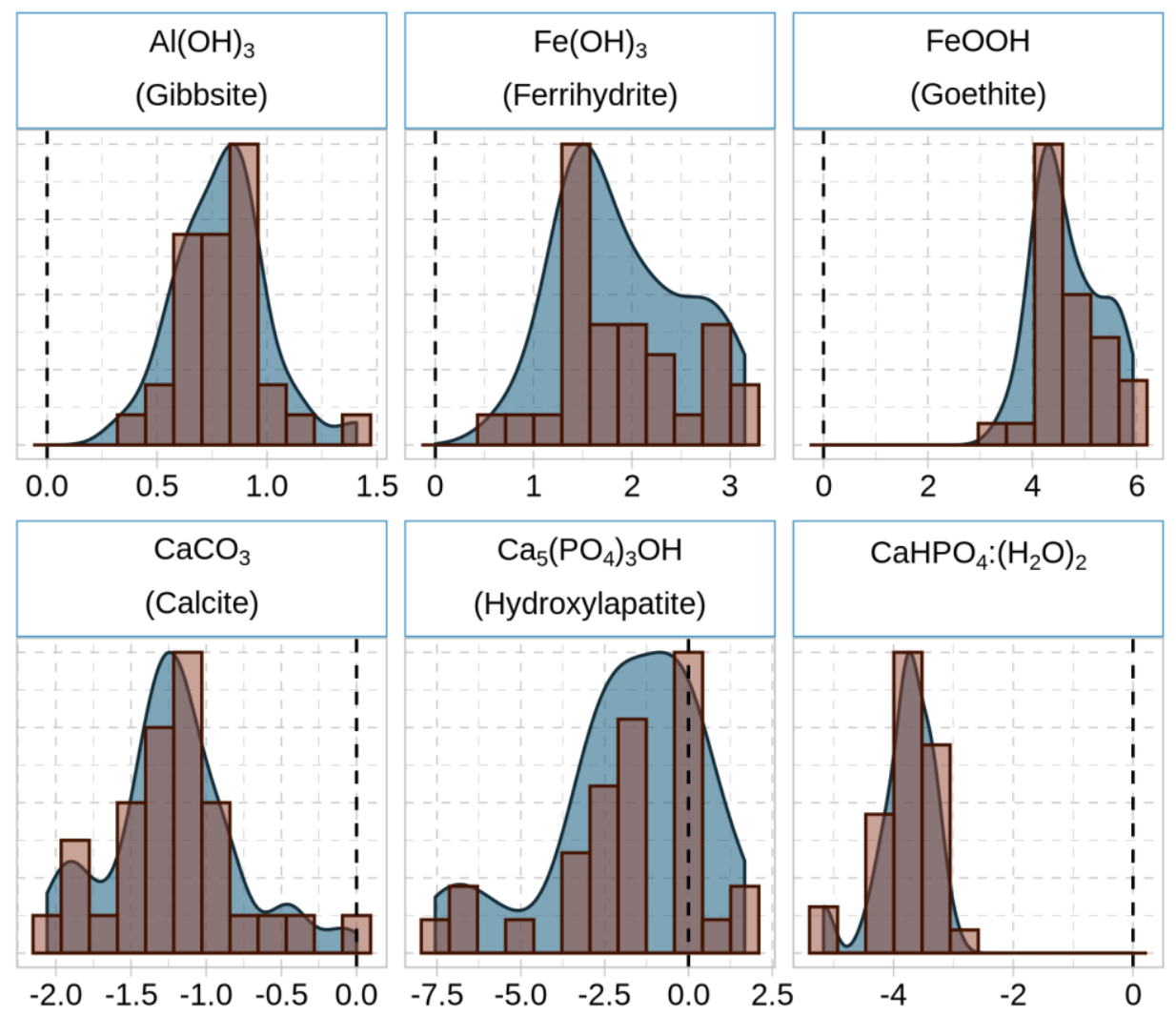

Mineral Saturation Index (SI)

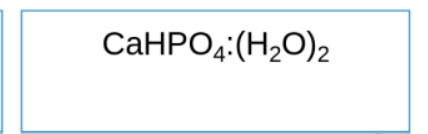


https://doi.org/10.5194/bg-2019-400

Preprint. Discussion started: 18 October 2019

(c) Author(s) 2019. CC BY 4.0 License.

(c) (i)

\section{Catchment geology}

- Alluvium - Sedimentary $\bigcirc$ Volcanic basic

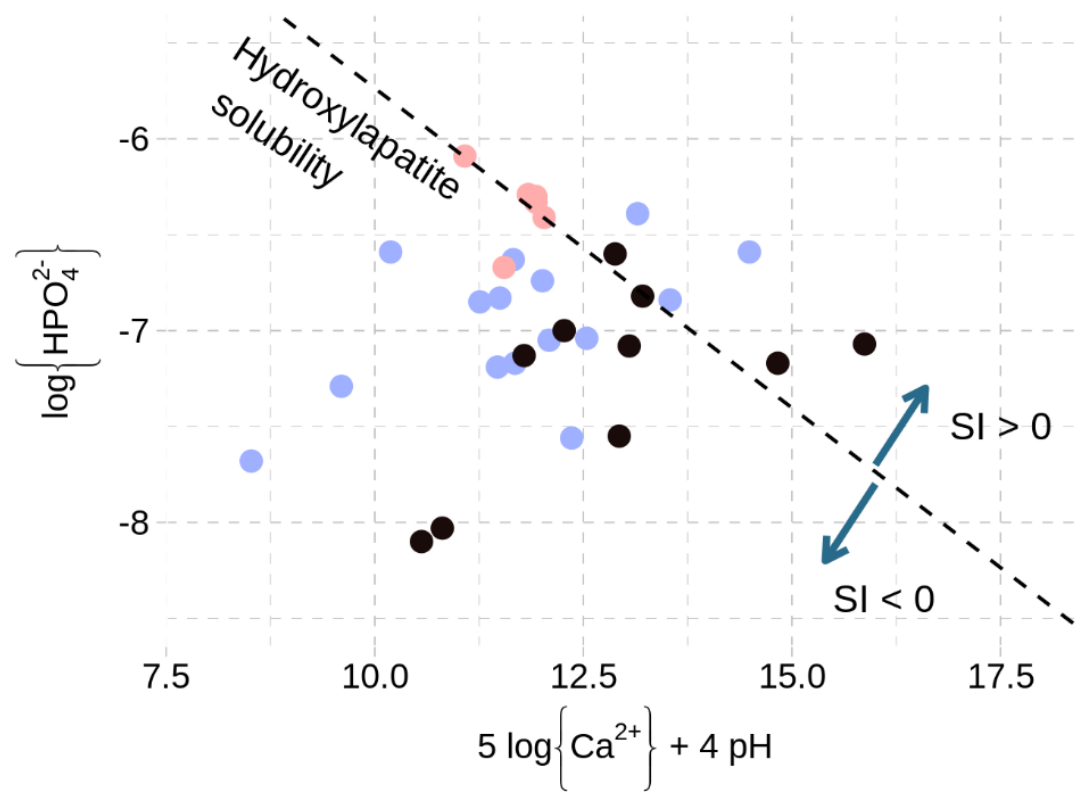

Figure 3. Log-activity of $\mathrm{HPO}_{4}{ }^{2-}$ plotted against a function of $\log$-activities of $\mathrm{Ca}^{2+}$ and $\mathrm{H}^{+}$for the stream samples $(n=31)$. The dashed line is a reference solubility line for hydroxylapatite, where points below (above) this line are likely sub-saturated (super-saturated) with respect to hydroxylapatite. 
https://doi.org/10.5194/bg-2019-400

Preprint. Discussion started: 18 October 2019

(c) Author(s) 2019. CC BY 4.0 License.
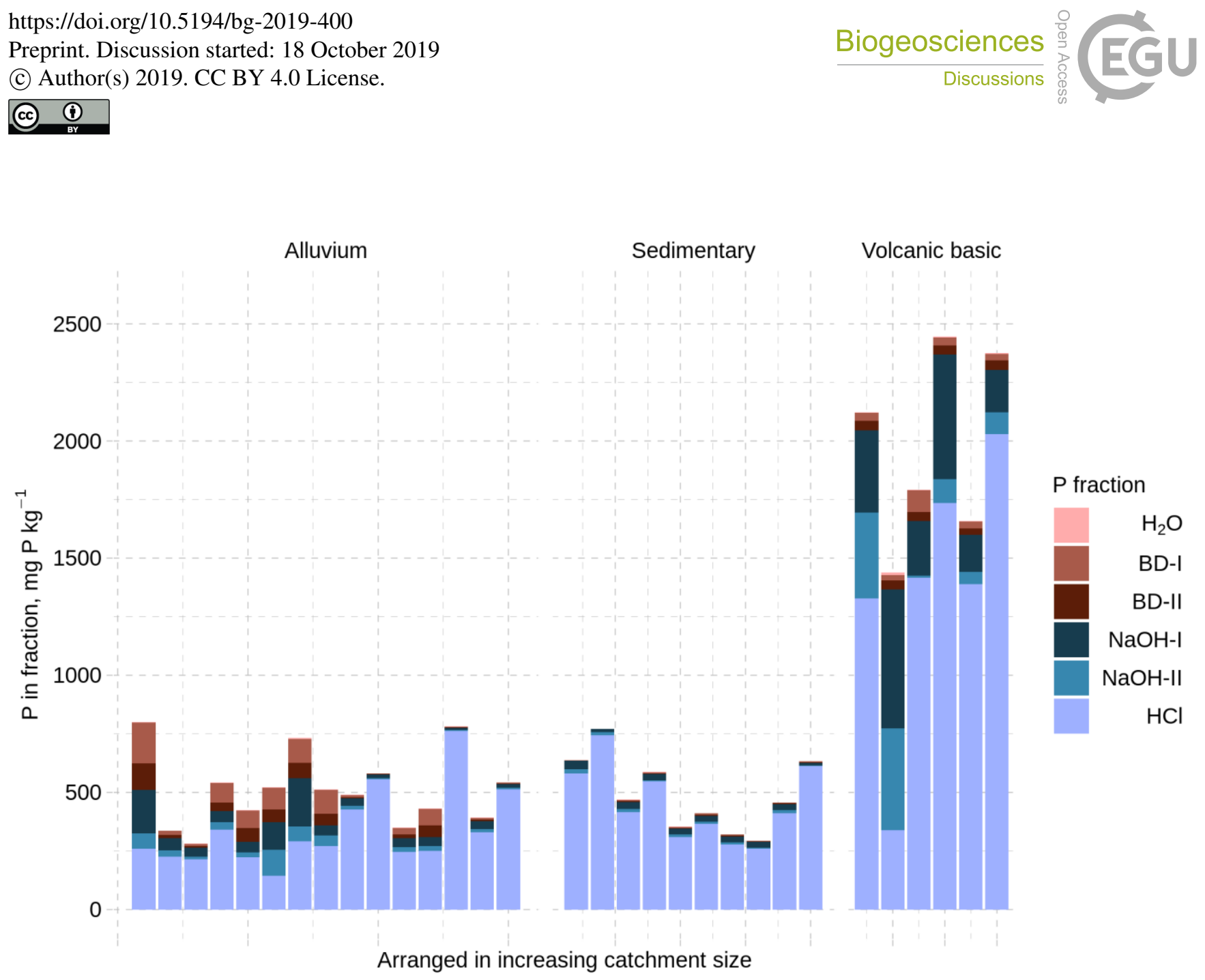

Figure 4. Benthic sediment $(<2 \mathrm{~mm})$ phosphorus content fractionated according to decreasing chemical lability; bars are arranged in increasing order of catchment size within the River Environment Classification geology class. 
https://doi.org/10.5194/bg-2019-400

Preprint. Discussion started: 18 October 2019

(c) Author(s) 2019. CC BY 4.0 License.
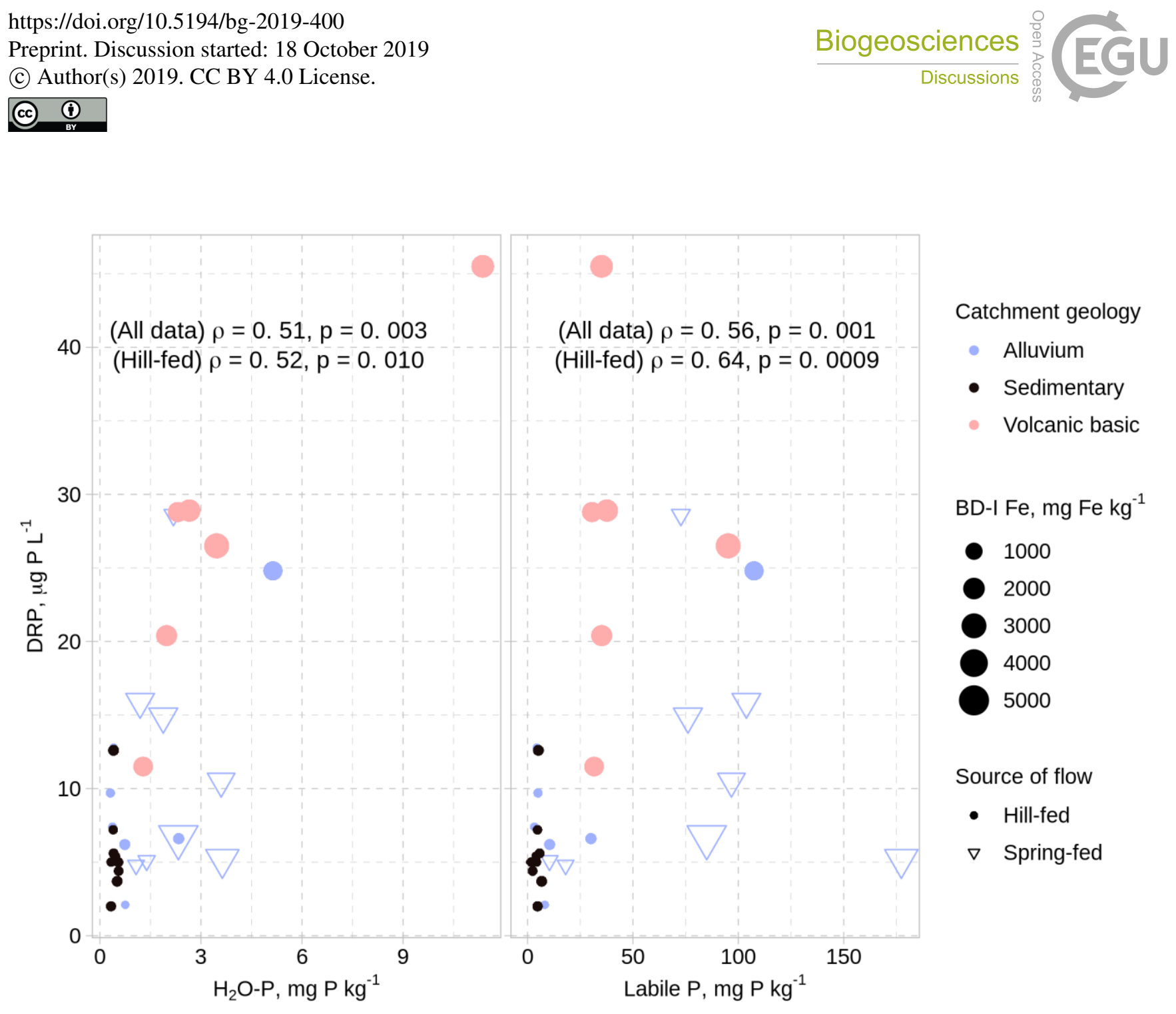

Figure 5. Stream DRP concentration as a function of sediment $\mathrm{H}_{2} \mathrm{O}-\mathrm{P}$ and sediment labile $\mathrm{P}\left(\mathrm{H}_{2} \mathrm{O}-\mathrm{P}\right.$ plus $\left.\mathrm{BD}-\mathrm{I} \mathrm{P}\right)$ concentrations from the sequential $P$ fractionations. Spearman correlation tests are shown for all data $(n=31)$ as well as for only hill-fed streams $(n=23)$. 
https://doi.org/10.5194/bg-2019-400

Preprint. Discussion started: 18 October 2019

(c) Author(s) 2019. CC BY 4.0 License.

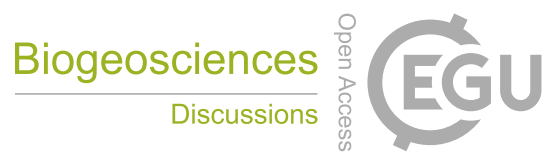

(c) ${ }_{\mathrm{Bv}}$

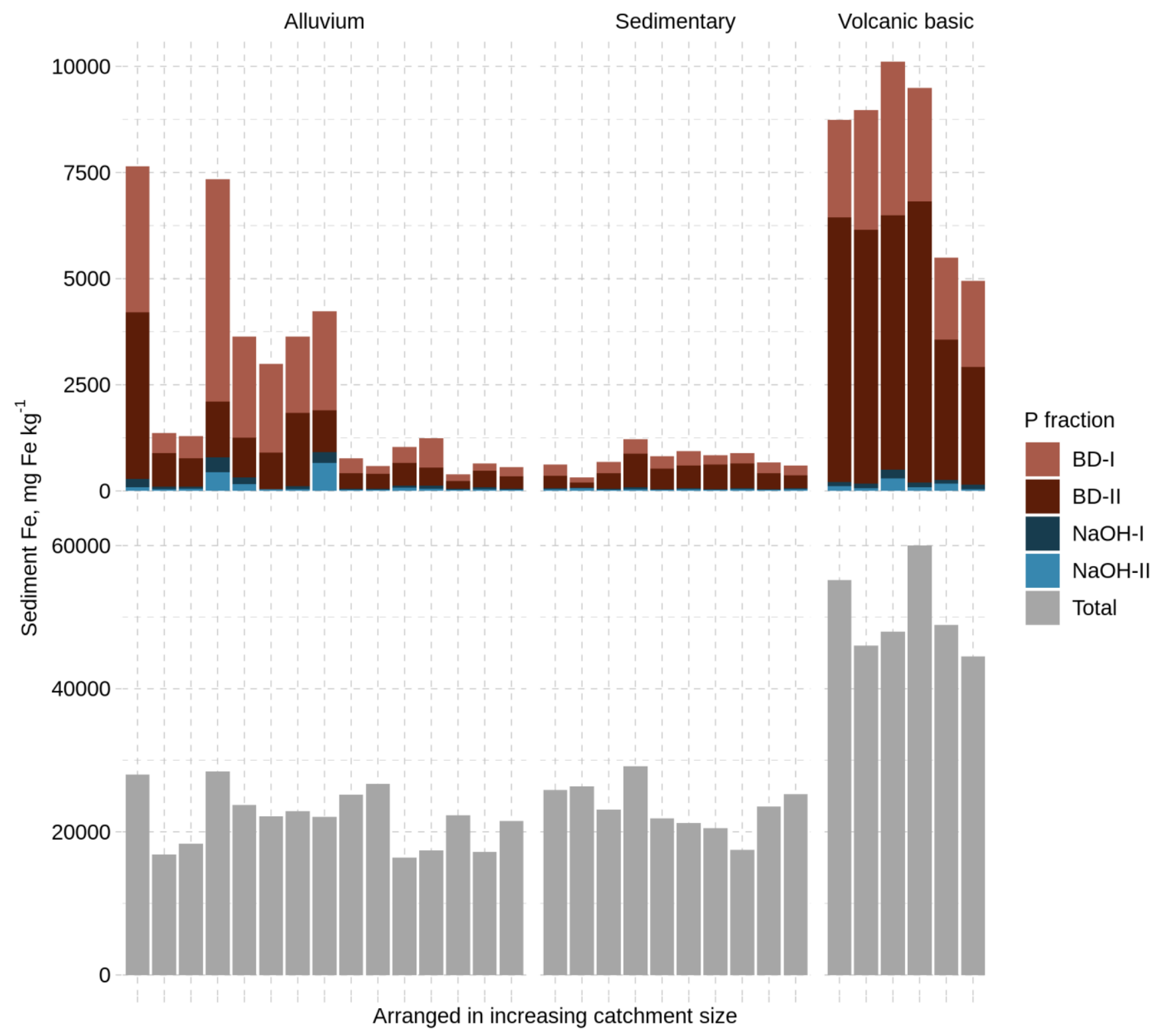

Figure 6. Sediment Fe concentration as measured in the $P$ fractions (potentially reactive Fe arranged in decreasing lability; top row) or as the total Fe concentration (bottom row); note the differences in scale. Each bar (site) is arranged in increasing catchment size within the River Environment Classification geology class. 
https://doi.org/10.5194/bg-2019-400

Preprint. Discussion started: 18 October 2019

(c) Author(s) 2019. CC BY 4.0 License.

(c) (1)
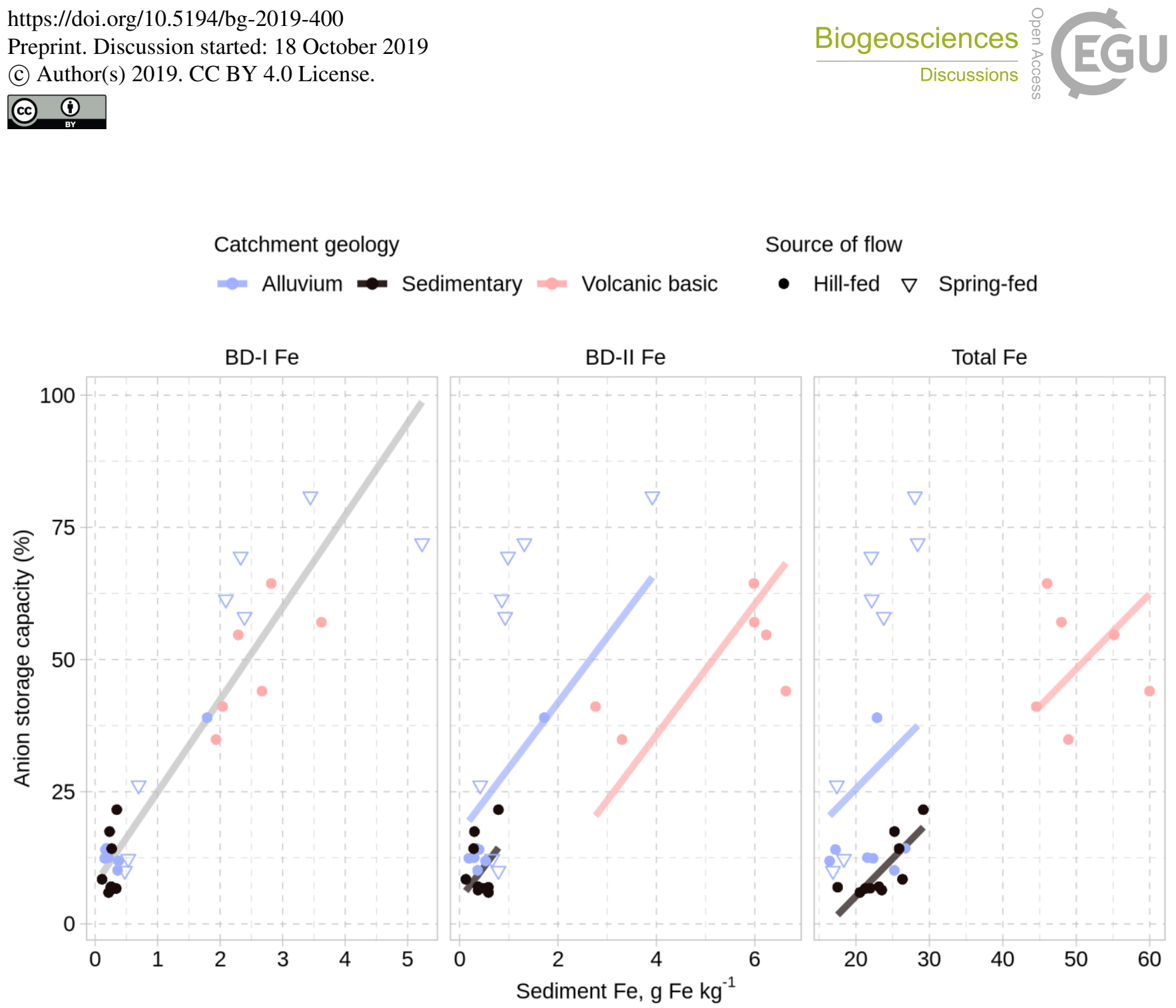

790

Figure 7. Sediment $P$ sorption potential as measured by anion storage capacity (ASC; \%) as a function of sediment Fe in the bicarbonate-dithionite (BD) extractable pools and total sediment Fe. The optimal robust linear models for ASC with each Fe fraction, as discussed in text, are shown; note that while BD-I Fe alone predicts ASC, the models for BD-II Fe and total Fe include catchment geology as a covariate. 
https://doi.org/10.5194/bg-2019-400

Preprint. Discussion started: 18 October 2019

(c) Author(s) 2019. CC BY 4.0 License.

(c) (1)
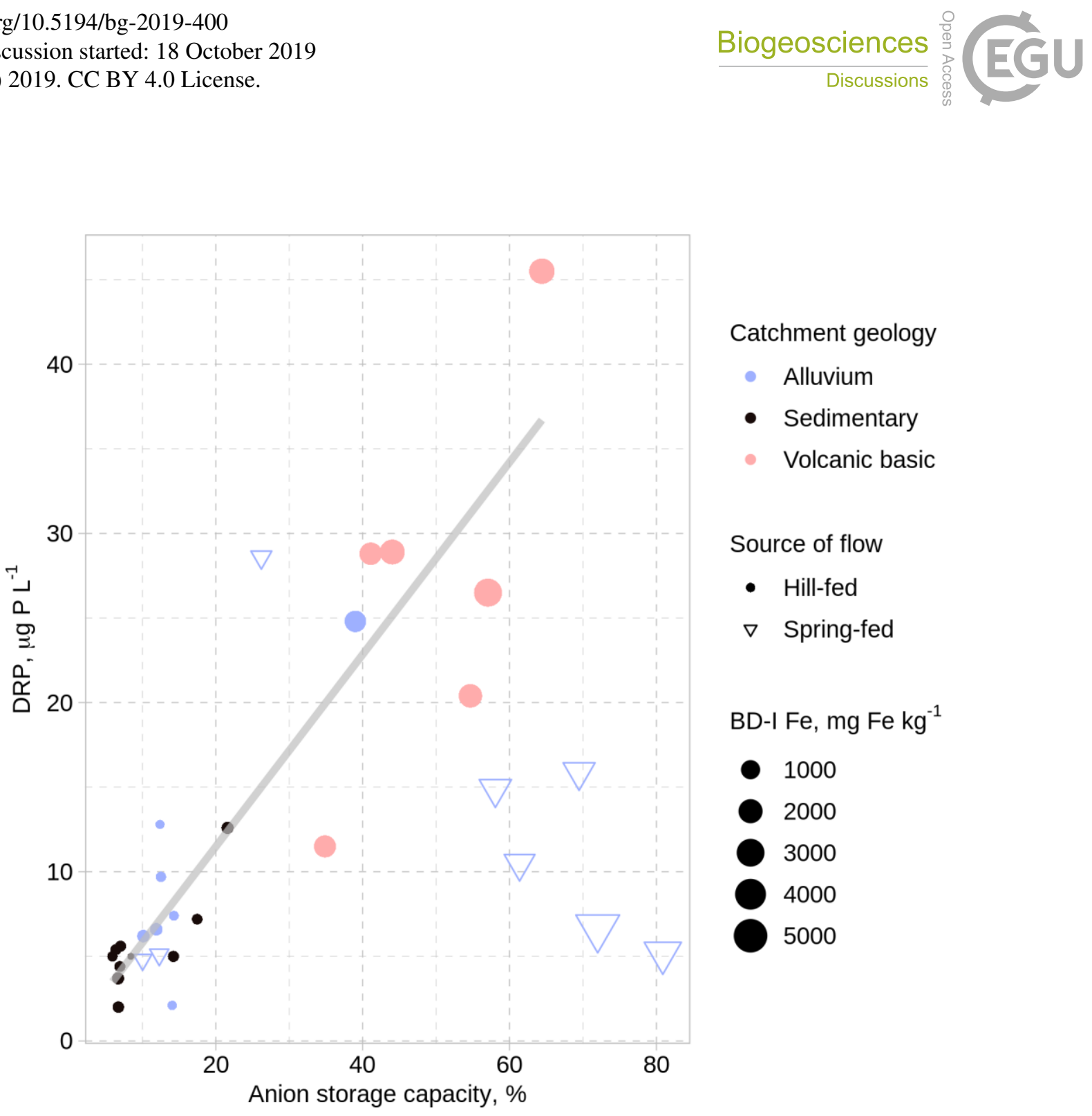

Figure 8. In-stream DRP as a function of sediment $P$ sorption metrics (anion storage capacity (ASC; \%) and Bache-Williams Index (BWI; refer to methods for unit interpretation)). The robust linear model discussed in text is shown. 